\title{
A CRITICAL ANALYSIS OF REDD+ LEGAL ARCHITECTURE IN REDUCING EMISSIONS FROM FORESTRY SECTORS IN INDONESIAN
}

\author{
I Gusti Agung Made Wardana ${ }^{1}$
}

\begin{abstract}
A new scheme called "Reducing Emissions from Deforestation and Forest Degradation in Developing Countries plus Conservation, Sustainable Management of Forests, and Enhancement of Forest Carbon Stocks" (REDD+) is being discussed to be one of the essential elements of the post-2012 global climate change regime. Many countries have put their proposal on the architectures of such scheme to the UNFCCC and demonstrated pilot projects on the ground as well. The research has been conducted to analyze critically the extent to which the REDD+ architecture being designed in Indonesia would be able to deliver climate effectiveness, costs efficient, equity outcomes and social and environmental co-benefits (3E+). It is argued that the basic idea of REDD+ is very simple to incentivize emission-reduction activities from forestry sectors in developing countries. However, so far, the REDD+ architecture appears to contain several contentious issues. Therefore, the issues should be addressed seriously otherwise they would undermine the REDD+ objectives.
\end{abstract}

Key words: climate change, environmental law, forestry, Indonesia, Post2012 Regime, REDD+, UNFCCC.

\section{Introduction}

The Kyoto Protocol's first commitment period ends in 2012. Recently, the state parties to the UNFCCC ${ }^{2}$ and its Kyoto Protocol ${ }^{3}$ have negotiated to formulate the next international regime to regulate anthropogenic causes of climate change. They expected that the regime would be adopted in the $17^{\text {th }}$ Conference of Parties (COP 17) in Durban, South Africa last year. However, due to challenging issues, delegates failed to reach an agreement. One of the biggest challenges was whether parties would continue the Kyoto Protocol as the only legally binding instrument under the UNFCCC. On the one hand, majority of developing countries have put a stance to have a second commitment period of the Kyoto Protocol as mandated by Article 3 (9) of the Protocol. ${ }^{4}$ On the other

\footnotetext{
${ }^{1}$ Author is a lecturer of international law at the National Education University of Denpasar, and member of Indonesian Advocate Association (PERADI). This article has been written to be a dissertation for Master of Laws (LLM) in Environmental Law at the School of Law, the University of Nottingham, UK. Author can be reached at <igam.wardana@yahoo.co.uk>

2 United Nations Framework Convention on Climate Change, adopted in 1992 during the UN Conference on Environment and Development in Rio, Brazil, and entered to force in 1994

${ }^{3}$ Kyoto Protocol to the United Nations Framework Convention on Climate Change (the Kyoto Protocol) was adopted in 1997 in Kyoto, Japan and entered into force in 2005

${ }^{4}$ Article 3 (9) of the 1997 Kyoto Protocol states, "[c]ommitment for subsequent periods for Parties included in Annex I shall be established in amendments to Annex B to this Protocol, which shall be adopted in accordance with the provisions of Article 21, paragraph 7." See Lin, Li Lim. (2010). We'll Never Accept
} 
hand, some developed countries have argued that a new agreement would be needed to replace the Kyoto Protocol for a more effective instrument ${ }^{5}$.

Despite such disagreement, a new initiative to reduce emissions from forestry sectors in developing countries is leaning to be "one of the key pillars of a post-2012 international climate regime". ${ }^{6}$ The initiative was first proposed by Costa Rica and Papua New Guinea "on behalf of many supportive Nations" in 2005. ${ }^{7}$ Furthermore, such initiative known as "Reduction Emissions from Deforestation in Developing Countries" [RED] was launched officially during COP 11 in Montreal in 2005 and to be negotiated through the Subsidiary Body for Scientific and Technological Advice [SBSTA]. Later, RED has developed further since COP 13 in Bali in 2007 into "Reducing Emission from Deforestation and Forest Degradation in Developing Countries" [REDD], then expanded into "Reducing Emissions from Deforestation and Forest Degradation in Developing Countries plus Conservation, Sustainable Management of Forests and Enhancement of Forest Carbon Stocks" [REDD+] during COP 14 in Poznan in 2008.

Indeed, REDD+ is a mitigation strategy to address emissions from land use and forestry sectors. According to the Intergovernmental Panel on Climate Change [IPCC], they contribute up to $17.4 \%$ of global anthropogenic greenhouse gas [GHG] emissions, or, according to Sir Nicholas Stern (2006:171), they are responsible for $18 \%$ of global emissions and mostly are driven by deforestation that occurs $30 \%$ in Indonesia and $20 \%$ in Brazil. Thus, a need to include deforestation into the international climate change regime by adopting REDD+ seems obvious. According to Randall Abate, the REDD+ is supported by almost all developed countries, including the US, and developing countries since it may fill the gaps left by the Kyoto Protocol as being an insufficient instrument to address global climate change. The gaps are: firstly, deforestation and forest degradation, significant sources of GHG, are excluded due to its complex methodological matters, potential leakage and loopholes; secondly, there is no "sufficiently effective mechanisms for developing countries to have a meaningful role in addressing climate change"; finally, the Protocol fails to bring the United States to participate fully under the regime. Concluded by him, therefore, REDD+ would be a win-win solution to bring both developing and developed countries on board of effective and efficient mitigation actions.

In fact, the concept of REDD+ seems simple but it may be very complicated in its details and implementation. Many issues have been argued both by proponents and by opponents of REDD+ with regard to technical and

$2^{\text {nd }}$ Kyoto Period, says Japan, Sparkling Doubts on KP's Survival, Third World Network (TWN) Cancun News Update 5 on 30 November 2010 (online) available at http://www.twnside.org.sg/ [accessed 9 July 2011]

${ }^{5}$ Japan, for example, announced at the first day of COP 16 Cancun that it would not support the extension of the Kyoto Protocol for the second commitment period. This position was followed by Russia, Australia, Canada and New Zealand. See MarthinKhor, What to Expect in Cancun: Some Key Issues, Third World Network (TWN) Cancun News Update 1 on 29 November 2010. Available at http://www.twnside. org.sg/

${ }^{6}$ E.Corbera and H. Schroeder, (2011). “Governing and Implementing REDD+”. 14 Environ. Sci. Policy, 2011.pp. 89-99

7 The "supportive nations" furthermore established the Coalition of Rainforest Nations, a collaboration of forested tropical countries such as Congo, Costa Rica, Indonesia, and Ecuador. See Friends of the Earth International (FoEI). (2008). REDD Myth: a Critical Review of Proposed Mechanisms to Reduce Emissions from Deforestation and Degradation in Developing Countries. Amsterdam: FOEI. p.9 
methodological matters, negative impacts on leakage, sources of finance, as well as on its guidance and safeguards. In response to this, a set of criterion is used as a tool to assess whether the architecture of REDD+ being designed could reach its objective to bring about climate effectiveness, cost efficiency, equity outcomes and generate co-benefits [3E+ criterion]. 'Effectiveness' refers to "the magnitude of the emission reduction achieved". Effectiveness would be depending on several factors, among others: political feasibility and commitment from participating countries and more importantly depending on "the design of the REDD model". 'Efficiency' refers "to whether the given emission reduction is achieved at a minimum cost". ' 'Equity' is related to distribution of REDD+ costs and benefits. ${ }^{10}$ Finally, 'co-benefit' refers to complementary benefit arising from REDD+ activities, and in relation to the goals of other international agreements, for example conservation of biodiversity and ecosystem services, and poverty alleviation. ${ }^{11}$

Given the REDD+ would be a new scheme under the next international climate regime, therefore, this paper aims to critically analyse the extent to which the REDD+ architecture being designed in Indonesia may reach the 3E+ criterion. The areas of focus are mainly on thedevelopment of the REDD+ scheme, including history, methodology, finance, and basic principles at the international level; and the architecture of REDD+ in Indonesia, including law and policies, institutional arrangements, and implementation of safeguards on the ground.

\section{The International REDD+ Architecture}

\section{A. Climate Change and Forestry Sectors}

Today, climate change is one of the biggest challenges facing international community. ${ }^{12}$ The impacts of climate change such as sea level rise, loss of biodiversity, food insecurity, floods, as well as climate refugees are resulting from an increase in GHG concentration in the atmosphere. Concerned with these impacts, in 1988, the UN General Assembly issued a Resolution 43/53 stated "climate change is common concern of humankind since climate is an essential condition, which sustains life on earth". ${ }^{13}$ Furthermore, the UN General Assembly agreed to establish an Intergovernmental Negotiation Committee [INC] in 1990. ${ }^{14}$ After several years negotiating, the INC produced a draft of the United Nations Framework Convention on Climate Change [UNFCCC] that was opened for signature during the 1992 UN Conference on Environment and Development [UNCED] in Rio, Brazil. The Convention has come into force since $21^{\text {st }}$ March 1994. In its $3^{\text {rd }}$ Conference of Parties [COP 3] Kyoto, Japan, a protocol

${ }^{8}$ A. Angelsen and S. Wertz-Kanounnikoff. (2008). What Are the Key Design Issues for REDD and the Criteria for Assessing Options? in Moving Ahead with REDD: Issues, Options and Implications. Ed. by. Arild Angelsen, p.8

${ }^{9}$ Ibid., p.19 Angelsen, p.5

${ }^{10}$ A. Angelsen (2009). Introduction in Realising REDD+: National Strategy and Policy Options. Ed.by.

${ }^{11}$ Ibid., p.4

12 D. French, (1998). "1997 Kyoto Protocol to the 1992 UN Framework Convention on Climate Change". 10 Journal of Environmental Law. 1998. pp. 227-239

${ }^{13}$ Paragraph 1 of the UNGA Resolution 43/53

${ }^{14}$ UNGA Resolution 45/221. For historical development of the international climate change regime, see Bodansky, D. (1993). The United Nations Framework Convention on Climate Change: A Commentary, 18 Yale Journal of International Law 451-558 
was agreed to implement the framework convention, known as the 1997 Kyoto Protocol. ${ }^{15}$

As far as sources of GHG are concerned, the IPCC differentiates the sources into two categories, namely natural and anthropogenic sources of GHG. ${ }^{16}$ While the natural sources are derived from natural phenomenon for example volcanic eruptions, the anthropogenic sources are human-induced GHG emissions through human activities for example burning fossil fuels, or land use, land-use change and forestry (LULUCF). If burning of fossil fuels and cement production has emitted $\mathrm{CO} 2$ around 270 gigatonnes (GtC) since the Industrial Revolution, about $136 \mathrm{GtC}$ of $\mathrm{CO} 2$ emissions has been emitted from land-use and forestry sectors in which tropical deforestation is counted as the most significant contributor. ${ }^{17}$ However, forest, in the context of climate change, has dual roles: as a carbon sequester in which trees in forests absorb $\mathrm{CO} 2$ and store it through the photosynthesis process; on the other hand, when its carbon stocks are released to the atmosphere from deforestation and forest degradation [DD] activities, forest becomes a major source of GHG emissions. ${ }^{18}$

Hence, forests particularly in the tropical forest regions are on the spotlight. Tropical forests are covering 15\% of the earth surface, containing 25\% of terrestrial carbon and 50\% of biodiversity, and being a livelihood for millions of indigenous and forest-dependent communities. Approximately 13 million hectares of tropical forest, equaled to the size of the United Kingdom, disappear every year, which take place $97 \%$ in tropical. ${ }^{19}$ Considering their importance in sustaining life on earth and their contribution as the second largest sources of GHG from DD, there is a vital need to involve forestry sectors under the climate regime, namely the UNFCCC and the Kyoto Protocol.

\section{The 1992 Climate Change Convention}

In Article 1 (2) of the UNFCCC, climate change is defined as "a change of climate which is attributed directly or indirectly to human activity that alters the composition of the global atmosphere and which is in addition to natural climate variability observed over comparable time period". Unlike the definition given by the IPCC that includes natural sources, the Convention seems primarily to address the sources of greenhouse gases derived from human activities that are not covered by the Montreal Protocol. ${ }^{20}$ Indeed, the UNFCCC covers a wide range of activities, from transportation, industry, waste management, to forestry, and regulates various substances from $\mathrm{CO} 2$ to Methane. In terms of the objective, Article 2 of the Convention stipulates,

"the ultimate objective of this convention and any related legal instruments

${ }^{15}$ D. French, Op.cit., pp. 227-239

${ }^{16}$ See definition of climate change given by the panel in IPCC. (2007). Climate Change 2007: Synthesis Report. n.p: IPCC. p.30

${ }^{17}$ E. Trines, (2008). History and Context of LULUCF in the Climate Regime' in Climate Change and Forests: Emerging Policy and Market Opportunities . Ed.by. C. Streck et al, p.34

18 N. Angerand J. Sathaye, (2008). Reducing Deforestation and Trading Emissions: Economic Implications for the Post-Kyoto Carbon Market, p.1

${ }^{19}$ C. Parker, et al. (2007). The Little REDD Book, p.10; M. Huftyand A. Haakenstad, "Reduced Emissions for Deforestation and Degradation: A Critical Review". 5 the Journal of Sustainable Development, 2011. p.1-2

${ }^{20}$ The Montreal Protocol on Substances that Deplete Ozone Layer to the Vienna Convention for the Protection of the Ozone Layer is adopted in 1987 in Montreal, Canada and come into force on 1 January 1989 
that the conference of the Parties may adopt is to achieve, in accordance with the relevant provisions of the Convention, stabilization of greenhouse gas concentrations in the atmosphere at the level that would prevent dangerous anthropogenic interference with the climate system."

The phrase 'ultimate objective' above may be interpreted as an ongoing objective of the Convention and may reflect the intention to set the Convention as a framework agreement which needs a protocol or protocols to set its shortterm goals. In Article 3, the Convention stipulates, "in their actions to achieve the objective of the Convention and to implement its provisions, the Parties shall be guided..." by a set of principles, inter alia, the principle of common but differentiated responsibilities, inter and intra generational equity, the precautionary principle, as well as sustainable development. Article 3 (1), for instance, emphasizes the importance to protect the climate system "for the benefit of present and future generation of humankind, on the basis of equity and in accordance with their common but differentiated responsibilities and respective capabilities. Accordingly, the developed country Parties should take the lead in combating climate change and the adverse effects".

The provisions on commitments under Article 4 of the Convention divide the commitments into general parties and specific parties (developed countries). Several commitments are stipulated regarding land use and forestry activities. All parties under Article 4 (1) shall undertake as follows: (a) developing, publishing and making available their national inventories of anthropogenic emissions by sources and removals by sinks of all GHG to the Conference of Parties; (b) formulating, implementing, publishing and regularly updating national and regional mitigation and adaptation programs; (c) cooperating and promoting the development, diffusion and application, transfer of climate-friendly technology; (d) promoting sustainable management of forests and cooperating in conserving and enhancing sinks and reservoir of all GHG.

Specifically for developed countries, Article 4 (2)(a) mandates that developed countries shall "adopt national policies and take corresponding measures on the mitigation of climate change, by limiting its anthropogenic emissions of greenhouse gases and protecting and enhancing its greenhouse gas sink and reservoirs". Article 4 (2) (b) stipulates that developed country parties shall "communicate within six months of the entry into force of the convention for it and periodically thereafter...detailed information on its policies and measures referred to in subparagraph (a) above, as well as on its resulting projected anthropogenic emissions by sources and removals by sinks of greenhouse gases not controlled by the Montreal Protocol for period referred to in subparagraph (a) [the end of the present decade], with the aim of returning individually and jointly to their 1990 levels these anthropogenic emissions of carbon dioxide and other greenhouse gases".

Preamble of the 1992 Climate Change Convention is "aware of the role and importance in terrestrial and marine ecosystems of sink and reservoirs" of GHG. It also recognizes that "steps required to understand and address climate change will be environmentally, socially and economically most effective if they are based on relevant scientific, technical and economic considerations and continually re-evaluated in the light of new findings in these areas", and affirms that "responses to climate change should be coordinated with social and economic development in an integrated manner." Furthermore, Article 
1 of the UNFCCC, reservoir is defined as "a component or components of the climate system where a greenhouse gas or a precursor of greenhouse gas is stored" and 'sink' is defined as "any process, activity or mechanism which removes a greenhouse gas, an aerosol or a precursor of greenhouse gas from the atmosphere".

In general, it seems that the commitments of the Convention are poorly drafted and often to be watered down by the language "taking into account their common responsibility and their specific national and regional development priorities, objectives and circumstances". Specifically on forestry issues, it appears that the issues are not really elaborated. Perhaps this is because as a framework convention the Convention is intended to stipulate more general commitments including general provisions on forestry sectors. One could argued that this may be due to the fact that during the negotiation, forestry issues were very contentious and considered as national sovereignty by some forested countries for example Brazil. Hence, by putting an argument on the principle of common but differentiated responsibility, tropical forested countries, mainly developing countries, were reluctant to regulate forestry sectors under the climate regime since it might affect their economic development. Moreover, another argument is due to the lack of scientific finding and poorly informed negotiators on the issues of forestry since climate change, at that time, was considered merely about burning of fossil fuel. ${ }^{21}$

\section{The 1997 Kyoto Protocol}

The 1997 Kyoto Protocol, coming into force in 2005, as the only legally binding protocol to implement the UNFCCC. The Protocol requires developed countries, either jointly or individually, to "ensure that their aggregate anthropogenic carbon dioxide equivalent emissions of the greenhouse gases listed in Annex A do not exceed their assigned amounts, calculated pursuant to their quantified emission limitation and reduction commitments inscribed in Annex A and in accordance with the provisions of this Article, with a view to reducing their overall emissions of such gases by at least 5 per cent below 1990 levels in the commitment period 2008-2012". ${ }^{22}$ There are 42 developed countries and the European Union that are listed as Annex 1 Parties to the UNFCCC [Annex 1 Parties] which oblige to reduce several types of GHG emissions stated in Annex A to the Kyoto Protocol with quantified emissions limitation or reduction commitment stipulated by Annex B to the Protocol.

The Protocol also covers several activities that shall be undertaken by parties. Article 2 (a) (ii), for instance, stipulates that Annex 1 Parties shall undertake the implementation and/or further elaboration of policies and measures in accordance with its national circumstances to protect and enhance sinks and reservoirs of GHG, and the promotion of "sustainable forestmanagement practices" and "afforestation/reforestation". Article 10 (b) stipulates that all parties shall "formulate, implement, publish and regularly update national and, where appropriate, regional programmes containing measures to mitigate climate change and measures to facilitate adequate adaption to climate change" including programmes and forestry.

\footnotetext{
${ }^{21}$ See for example Streck, C. (2008) Forest, Carbon Markets, and Avoided Deforestation: Legal Implications, 3 CCLR. 240

${ }^{22}$ Article 3 (1) of the 1997 Kyoto Protocol
} 
In order to assist Annex 1 Parties meeting their commitment, there are three flexible mechanisms set under the Protocol and guided by the Marrakesh Accord $^{23}$, namely the Joint Implementation, the Clean Development Mechanism, and the Emission Trading. First of all, Joint Implementation (JI) is set under Article 6 of the Protocol to allows an Annex 1 Party earning emission reduction units (ERUs) from a project to reduce or remove emissions in another Annex 1 Party in which amount of reduction can be used to meet its commitment. ${ }^{24}$ Secondly, the Emission Trading (ET) scheme under Article 17 of the Kyoto Protocol allows cooperation within Annex 1 Parties by buying and selling "Certified Emissions Reductions" (CERs), "Assigned Amount Units" (AAUs), "Emissions Reduction Units" (ERUs) or "Removal Units" (RMUs). ${ }^{25}$ Finally, the Clean Development Mechanism (CDM) set under Article 12 of the Protocol allows an Annex 1 Party to implement a project to reduce emissions in developing countries (Non-Annex 1 Parties). Amount of emissions reduction stated by Certified of Emissions Reductions (CERs) arising form such project can be counted to meet the reduction target of the Annex 1 Party or can be sold to other Annex 1 Parties. ${ }^{26}$

In terms of LULUCF activities in the first Kyoto Protocol commitment period, while the JI does not restrict and limit the implementation of LULUCF activities, the inclusion of such activities is limited and restricted under the $\mathrm{CDM}^{27}$ Indeed, at the beginning, 'avoided deforestation' were proposed by several countries to be an eligible LULUCF activity under the CDM. However, the proposal was rejected due to the complexity of its methodology, namely additionality, permanence, baseline, leakage as well as its possible negative impacts on biodiversity. ${ }^{28}$ Another reason of such rejections was argued by the EU, among others, saying that the integration CERs from avoided deforestation activities into emission trading schemes might badly influence the development of new climate-friendly technology and might drop the price of emission credits from other sectors since Annex 1 Parties would likely use the cheaper credits from avoided deforestation to meet their emission-reduction target. ${ }^{29}$ Therefore, the compromise was the inclusion of Afforestation ${ }^{30} /$ Reforestation $^{31}(A / R)$ as the only LULUCF activities under the CDM since A/R activities are less complex to measure and monitor. ${ }^{32}$

\footnotetext{
${ }^{23}$ FCCC/CP/2001/13/Add.1

${ }^{24}<$ http://unfccc.int/kyoto_protocol/mechanisms/joint_implementation/items/1674.php> accessed 9 July 2011 9 July 2011

25 <http://unfccc.int/kyoto_protocol/mechanisms/emissions_trading/items/2731.php> accessed

${ }^{26}<$ http://unfccc.int/kyoto_protocol/mechanisms/clean_development_mechanism/items/2718. php> accessed 9 July 2011

${ }^{27}$ E. Trines, Op.cit., p. 34

${ }^{28}$ M. Hufty and A. Haakenstad, Op.cit., p.3

${ }^{29}$ J. Ebeling, (2008). Risk and Criticisms of Forestry-Based Climate Change Mitigation and Carbon Trading in Climate Change and Forests: Emerging Policy and Market Opportunities. Ed.by. C. Streck et al, p.44

${ }^{30}$ Afforestation is "the direct human-induced conversion of land that has not been forested for period of at least 50 years to forested land through planting, seeding and/or the human-induced promotion of natural seed sources". See Marrakesh Accords, FCCC/CP/2001/13/Add.1, para. 1(b) 58

${ }^{31}$ Reforestation is "the direct human-induced conversion of non-forested land to forested land through planting, seeding and/or the human-induced promotion of natural seed sources, on land that was forested but that has been converted to non-forested land. For the first commitment period, reforestation activities will be limited to reforestation occurring on those lands that did not contain forest on 31 December 1989". See Marrakesh Accords, FCCC/CP/2001/13/Add.1, para. 1(b) 58

${ }^{32}$ Ian Fry, "Reducing Emissions from Deforestation and Forest Degradation: Opportunities and Pitfalls
} 
In fact, LULUCF rules under the Kyoto Protocol are contentious. The rules have been criticized by many developing countries as lack of environmental integrity since Annex 1 Parties may choose which activities they consider to implement Article 3 (4) of the Protocol from forest management, revegetation, crop land management to grassing land management (FIELD 2011:6). ${ }^{33}$ Specifically on the A/R CDM, such scheme has no significant influence in meeting the target of emission-reduction since it only reflects $1 \%$ of the overall CDM projects during the first commitment period. The scheme has arguably encouraged the expansion of monoculture plantation in some developing countries due to, among others, its unclear modalities. Moreover, LULUCF activities are less attractive to private sectors because of complicated requirements and delayed procedures due to difficulty in reaching agreement, which may influence the cost of implementation. ${ }^{34}$

\section{B. Development of REDD+}

While the REDD+ architecture is being designed, there are many strategies in place at international levels to deal with forestry issues. One strategy mandated by Article 8 (a) of the 1992 Convention of Biological Diversity is by establishing protected areas, which have covered around 13.5\% of all forest areas in the world. Others strategies are through international agreements for example the 2006 International Tropical Timber Agreement (IATT 2006), or through multilateral forums led by either the Food and Agriculture Organisation (FAO) or the United Nations Forum on Forests (UNFF), as well as through certification schemes, among others, the Forest Stewardship Council (FSC). It is argued that these strategies in certain circumstances have been able to encourage good practices in forestry activities; when the rate of deforestation is taking into account, however, they appears to be insufficient to decrease deforestation. They are unable to create effective global forest governance since it is more likely to be fragmented, segmented, incoherent, underfunded and even nonlegally binding. ${ }^{35}$

In this regard, it is expected that the future REDD+ scheme would fill the gap of the existing strategies. Many observers seem optimistic with REDD+ since: (1) REDD+ involves new strategies, namely 'performed-based payment'; (2) strong willingness to pay for REDD+ have been demonstrated by international community; (3) a strong will to address DD has also been shown by many developing countries by integrating REDD+ as a part of low carbon development; (4) potential negative impacts of REDD+ are monitored and concerned by many organizations and individuals helping international community to design effective, efficient and equitable REDD+ schemes; (5) evidence on severe impacts of climate change and the need to adapt and mitigate such impacts are increasingly real and crucial. ${ }^{36}$

\section{Road to the Bali Action Plan}

in Developing a New Legal Regime”. 17 RECIEL, 2008. pp. 166-167 June 2011]

${ }^{33}$ FIELD, (2011). Guide for REDD-plus Negotiators. Available at <www.field.org.uk> [accessed 27

${ }^{34}$ J. Ebeling, Op.cit., pp. 43-44

${ }^{35}$ M. Hufty and A. Haakenstad, Op.cit., p.2

${ }^{36}$ F. Seymourand A. Angelsen, (2009). Summary and Conclusions: REDD Wine in Old Wineskins?' in Realising REDD+: National Strategy and Policy Options. Ed.by ArildAngelsen, pp. 302-303 
REDD+ as a 'win-win' solution for both developing and developed countries has been developed rapidly under the UNFCCC process. Currently, many architectures of REDD+ have been proposed and remain experimental until the most suitable architecture is adopted in by parties under the post-2012 regime. Historically, the first proposal for emission reduction from deforestation was officially put on the table by Papua New Guinea and Costa Rica on behalf of other supporting countries (the Coalition for Rainforest Nations) in COP 11 Montreal 2005. This proposal on "Reducing emissions from deforestation in developing countries (RED): approaches to stimulate action" suggested the parties to compensate or provide incentive for tropical forested countries in avoiding deforestation. As a result, COP 11 Montreal in 2005 encouraged parties and other accredited observers to put submissions on issues of emission-reduction from deforestation in developing countries and requested the Secretariat to conduct workshops on such issues. ${ }^{37}$

Three workshops have been organized under the auspices of the Subsidiary Body for Scientific and Technological Advice (SBSTA). The first workshop was on RED, 30 August-1 September 2006, in Rome, Italy, with three main issues, namely (a) scientific, socio-economic, and methodological issues, including the role of forests; (b) policy approaches and positive incentives including capacitybuilding and financial mechanisms; and (c) identification of possible links between issues (a) and (b). ${ }^{38}$ Participants agreed that RED "should contribute to the meeting the objective of the UNFCCC" and "to the alleviation of poverty" 39 , taking into account the causes of deforestation, social-economic factors, and their relationship with the possibility of leakage. ${ }^{40}$ However, several points were not really elaborated, namely methodology and financial sources. Neither did the workshop discuss the potential impacts of RED on biodiversity and forestdependent communities.

The second workshop on RED was in Cairns, Australia, from 7 - 9 March 2007 in which two main issues were discussed. The first issue was regarding "ongoing and potential policy approaches and positives incentives, and technical and methodological requirements related to their implementation", and the second one was focusing on "improving the understanding" of RED. ${ }^{41}$ The participants noted the need of urgent actions to implement RED while "ensuring the integrity of the international climate arrangement" ${ }^{42}$, and the need of building capacities and strengthening appropriate institutions to ensure effective participation of developing countries. ${ }^{43}$ With regard to principles, RED should be guided by "commonly agreed principles" including 'effectiveness, efficiency and appropriateness' 44 , polluter pays principles, the principle of common but differentiated responsibilities, respect state sovereignty, and the principle of equity and fairness. ${ }^{45}$ However, despite the fact that some methodological matters were discussed intensively, the workshop was far from

\footnotetext{
${ }^{37}$ FCCC/CP/2005/5, para.81

${ }^{38}$ FCCC/SBSTA/2006/10, para.3

${ }^{39}$ FCCC/SBSTA/2006/10, para.50

${ }^{40}$ FCCC/SBSTA/2006/10, para.52

${ }^{41}$ FCCC/SBSTA/2007/3, para. 2

${ }^{42}$ FCCC/SBSTA/2007/3, para.37

${ }^{43}$ FCCC/SBSTA/2007/3, para.38

${ }^{44}$ FCCC/SBSTA/2007/3, para.43

${ }_{45}$ FCCC/SBSTA/2007/3, para.44
} 
reaching an agreement on such matters. Debates on baseline or reference levels, definitional issues, permanence and leakage as well as sources of finance were the most contentious topics. ${ }^{46}$

Finally, the third workshop was on "Methodological Issues Relating to Reducing Emissions from Deforestation and Forest Degradation in Developing Countries" held on 25-27 June 2008 in Tokyo, Japan. Before the workshop, at the twenty-sixth session of the SBSTA Meeting in Bonn 2007, the SBSTA issued a proposed draft to be adopted in COP 13 Bali, December 2007. Some provisions on the proposed draft were optional in language by putting brackets or phrases 'taking into account', 'taking note of', or 'as appropriate' ${ }^{47}$ for several controversial issues, namely whether national circumstances of developing countries as proposed by some parties ${ }^{48}$ and the report of the Second Workshop should be expressed explicitly in the text ${ }^{49}$. The draft also proposed recognition of the 'effort and action to reduce deforestation, maintain, and conserve forest stocks' that have taken place in developing countries. ${ }^{50}$ This provision was trying to expand the scope of RED, as proposed by India, and Costa Rica, to include conservation and sustainable forest management practiced in developing countries. ${ }^{51}$

At the Bonn meeting shortly before COP 13, parties agreed that RED "can promote co-benefit and may complement the aims and objectives of other relevant international conventions and agreements". This means that the parties were aware that addressing deforestation should not be isolated from the social-economic factors that drive deforestation and should learn from the weaknesses of previous forest-related regimes. Still, the issues of forest-dependent communities were not elaborated in the draft although some countries, among others, Bolivia, raised their concern on the impacts of RED on indigenous peoples and local communities during the meeting.

\section{Bali Action Plan and Beyond}

During COP 13 Bali, Indonesia, based on the draft text provided by the SBSTA Meeting in Bonn 2007, the parties were negotiating RED. After more than two weeks negotiating, they agreed to release the Bali Action Plan as a road map to the next international climate change regime (post-2012) and widened the scope of RED to cover forest degradation, becoming "Reduction Emissions from Deforestation and Forest Degradation in Developing Countries" (REDD.) It seems clear that REDD would play an essential role in the 2012 international climate regime as it received special attention at COP 13. Indeed, the Bali Action Plan in its Decision 1/CP.13, Paragraph 1, decides

"to launch a comprehensive process to enable the full, effective and sustained implementation of the Convention through long-term cooperative action, now, up to and beyond 2012, in order to reach an agreed outcome

\footnotetext{
${ }^{46}$ See FCCC/SBSTA/2007/3, paras.45-86

${ }^{47}$ FCCC/SBSTA/2007/L.10, para.6 (options 1)

${ }^{48}$ See FCCC/SBSTA/2007/MISC. 2

${ }^{49}$ See FCCC/SBSTA/2007/3

${ }^{50}$ FCCC/SBSTA/2007/L.10, preamble

${ }^{51}$ See also The Ministry of Environment and Forests of India. (2009). Climate Change Negotiations:
} India's Submission to the United Nations Framework Convention on Climate Change (online) available at <moef.nic.in/downloads/home/UNFCCC-final.pdf> [accessed 20 August 2011] p.26 
and adopt a decision at its fifteenth session, by addressing...(b) [e]nhanced national/international action on mitigation of climate change, including... consideration of...(iii) [p]olicy approaches and positive incentives on issues relating to reducing emissions from deforestation and forest degradation in developing countries; and the role of conservation, sustainable management of forests and enhancement of forest carbon stocks in developing countries". ${ }^{52}$ [emphasis added]

In COP 13, the REDD initiative was intended to be part of mitigation actions from forestry sectors in developing countries. However, it is unclear how the initiative would relate to Land Use, Land-Use Change and Forestry (LULUCF) and A/R CDM that have been exist under the Kyoto Protocol. In Decision 2/ CP.13 on "Reducing Emissions from Deforestation in Developing Countries: Approaches to Stimulate Action", several points proposed by the draft text of the SBSTA were compromised but some new issues were agreed. Instead of using phrase 'concerning' the contribution of emissions from deforestation, the preamble uses 'acknowledging' the contribution of such emissions from deforestation as moderation ${ }^{53}$. The potential role of reducing emissions from DD in developing countries is also recognised as an actions in "helping to meet the ultimate objective of the Convention". ${ }^{54}$

Issues concerning the potential impacts of REDD on indigenous peoples and local communities are also mentioned by recognising that the needs of such peoples and communities should be addressed. Moreover, in Decision 2/CP.13, parties are invited to "further strengthen and support ongoing efforts to reduce emissions from deforestation and forest degradation on a voluntary basis". The parties are also encouraged to "support, provide technical assistance, facilitate the transfer of technology" in building the capacity of developing countries on methodological approaches including collecting, reporting and monitoring as well as arranging appropriate institutions. ${ }^{55}$ As the first official adoption of REDD, the Decision seems to focus mostly on general provisions in order to put all parties on board by avoiding the controversial issues for example on the issues of financial resources.

However, the Bali Action Plan does provide an indicative guidance in its annex. Several points adopted in the guidance are as follow: "demonstration activities should be undertaken with the approval of the host Party"; estimation of emission reduction should be "result based, demonstrable, transparent and verifiable, and estimated consistently over time"; emission reduction should be based on "historical emissions"; and the use of 'independent expert review' is encouraged. ${ }^{56}$ Furthermore, REDD is mandated to be negotiated under two tracks, namely in the Ad Hoc Working Group on Long Term Cooperative Action $(\mathrm{AW}-\mathrm{LCA})^{57}$ on the issues of REDD policy approaches and in the SBSTA on the

${ }^{52} \mathrm{FCCC} / \mathrm{CP} / 2007 / 6 /$ Add.1, p.3

${ }^{53}$ See Decision 2/CP.13, FCCC/CP/2007/6/Add.1, preamble

${ }^{54}$ See Decision 2/CP.13 (n 58)

${ }^{55}$ Decision 2/CP.13 (n 58)para.1

${ }^{56}$ Annex of Decision 2/CP.13, FCCC/CP/2007/6/Add.1 adopted on $8^{\text {th }}$ Plenary Meeting, $14-15$ December 2007

${ }^{57}$ Ad Hoc Working Group on Long-Term Cooperative Action (AW-LCA) is a working group established by the Bali Action Plan focusing on the development of cooperation between Annex 1 and NonAnnex 1 Countries on the issues of mitigation, adaptation, transfer of technology, and finance. Together with the Ad Hoc Working Group on the Further Commitment of Annex 1 Countries under the Kyoto Protocol 
issues of technical aspects. ${ }^{58}$

REDD has been further developed by other COP Decisions, namely by COP 14 Poznan in 2008, and COP 15 Copenhagen in 2009 as well as by COP 16 Cancun in 2010. In Poznan, the provisions "the role of conservation, sustainable management of forests and enhancement of forest carbon stocks" after semi colon in Decision 1/CP.13 (the Bali Action Plan) was developed as an integral part of the REDD initiative. Thus, the scope of the initiative has expanded further from (REDD) into "Reducing Emissions from Deforestation and Forest Degradation in Developing Countries plus Conservation, Sustainable Management of Forests and Enhancement of Carbon Stocks" (REDD-plus or REDD+).$^{59}$

In COP 15 Copenhagen in 2009, financial source of REDD+ was given a special attention. Paragraph 6 of the Copenhagen Accord recognises the need to establish the REDD+ mechanism immediately "to enable the mobilisation of financial resources" including from markets. ${ }^{60}$ In the Decision 4/CP.15, developing countries are requested to identify drivers of DD and activities that reduce emissions, increase removals and stabilise forest carbon stocks, as well as to establish "robust and transparent national forest monitoring systems". 61

In the context of indigenous groups and local communities, although the preamble of the Decision 4/CP.5 recognises "the need for full and effective engagement of indigenous peoples and local communities", this provision seems to be watered down by Paragraph 3 by giving qualification 'as appropriate' to develop guidance for such engagement. Some delegates criticised the Copenhagen Accord as an attempt to replace the Kyoto Protocol and rejected the adoption of it. However, for others, the Accord was considered as a win-win agreement between developing and developed countries due to the involvement of the US that is not a party to the Kyoto Protocol and the pledges from developed countries to mobilise financial resources that are needed by developing countries in their immediate adaption programmes. Finally, the Accord just took 'note of' by the parties.

The Cancun Agreement, the decision of COP 16, encourages developing countries to contribute "to mitigation actions in the forestry sectors by undertaking the following activities: (a) reducing emissions from deforestation; (b) reducing emissions from forest degradation; (c) conservation of forest carbon stocks; (d) sustainable management of forests; and (e) enhancement of forest carbon stocks". ${ }^{62}$ In addition, they are also requested to develop "(a) a national strategy or action plan; (b) a national forest reference emission level and/or forest reference level; (c) a robust and transparent national forest monitoring system; (d) a system for providing information on how the safeguard...are being addressed". ${ }^{63}$ Developing countries shall also "address the drivers of deforestation and forest degradation, land tenure issues, forest governance issues, gender considerations, and the safeguard (Appendix 1)", and ensure

(AW-KP), the AW-LCA was mandated to report to the COP 15 in Copenhagen, Denmark.

${ }^{58}$ V. Hollowayand E. Giandomenico (2009).Carbon Planet White Paper: The History of REDD Policy, p.13

\footnotetext{
${ }^{59}$ FCCC/SBSTA/2008/L.23, para.6

${ }^{60}$ See FCCC/CP/2009/11.add.1

${ }^{61}$ Decision 2/CP.15, FCCC/CP/2009/11/Add.1, para.1,

${ }^{62}$ Decision 1/CP.16, FCCC/CP/2010/7/Add.1, para.70,

${ }_{63}$ Decision 1/CP.16 (n 67) para.71
} 
"full and effective participation of relevant stakeholders" including indigenous groups and local communities. ${ }^{64}$

With regard to financial sources of REDD+, the AW-LCA was mandated to explore the financing options and to report its recommendation in COP 17 Durban, South Africa in $2011 .^{65}$

From the beginning, an initiative to have avoided deforestation seems controversial, especially in the context of the rights of indigenous peoples and local communities. Long experience of injustices and consideration of forest as a livelihood, indigenous peoples and local communities have raised their concerns on how avoided deforestation could affect their way of life and rights. Their voices have been represented by some countries especially Bolivia ${ }^{66}$, NGOs like Friends of the Earth International ${ }^{67}$ or Forest People Programme ${ }^{68}$ or even grassroots organisations like Indigenous Environmental Network. ${ }^{69}$ In fact, not until COP 14 Poznan in 2008, their voice had not been taken seriously, since parties appeared to be more concerned on putting the REDD scheme in place as soon as possible.

In response to many concerns raised by some Parties, NGOs and indigenous groups, the Cancun Agreement is complemented by an Appendix 1 on "guidance and safeguard for policy approaches and positive incentives on issues relating to reducing emissions from deforestation and forest degradation in developing countries; and the role of conservation, sustainable management of forests and enhancement of forest carbon stocks in developing countries" [Appendix 1 on REDD+ Guidance and Safeguard]. Paragraph 1 of the Appendix 1 provides guidance on several contentious issues including the fact that REDD+ should contribute to the achievement of the ultimate objective the UNFCCC and the fulfilment of the commitment from developed countries in terms of financial support. In addition, REDD+ should be voluntary and result based, "consistent with national sustainable development needs and goals" and "in the context of sustainable development and reducing poverty" with "adequate and predictable financial and technological" support. ${ }^{70}$

In addition, the safeguard highlights several issues. Among them are concerning: transparency and effectiveness of forest governance; respect to "the knowledge and rights of indigenous peoples and members of local communities" as well as their full and effective participation; biodiversity by ensuring that REDD+ is not used to encourage conversion of natural forests to monoculture plantation; leakage by addressing "the risk of reversal". ${ }^{71}$ However, instead of explicitly putting the issues concerned above as an obligation to comply with, such concerns appear to be undermined by a weak language that the safeguards should be "promoted and supported". In addition, the Cancun Agreement is also

\footnotetext{
${ }^{64}$ Decision 1/CP.16 (n 67) para.72

${ }^{65}$ Decision 1/CP.16 (n 67) para.77

${ }^{66}$ See Bolivian Submission to AWG-LCA on Universal Declaration on the Rights of Mother Earth

${ }^{67}$ See Friends of the Earth International (FoEI). (2008). REDD Myth: a Critical Review of Proposed Mechanisms to Reduce Emissions from Deforestation and Degradation in Developing Countries. Amsterdam: FOEI

${ }^{68}$ See T. Griffiths, (2008). Seeing 'REDD'?: Forest, Climate Change Mitigation and the Rights of Indigenous Peoples and Local Communities. UK: Forest People Programme

${ }^{69}$ See a join publication of social movement on REDD+ in Cabello, J., and Gilberston T. (n.d) No REDD. Mexico: Carbon Trade Watch and Indigenous Environmental Network

${ }^{70}$ Appendix 1 on REDD+ Guidance and Safeguard, FCCC/CP/2010/7/Add.1, para.1,

${ }^{71}$ Appendix 1 on REDD+ Guidance and Safeguard. supra note 75. para.2
} 
absence of compliance mechanisms. ${ }^{72}$ Although the safeguards are essential for an effective and equitable the REDD+ mechanism, it remains unclear what the legal consequences would be if the safeguards are violated.

\section{The REDD+ Building Blocks}

In designing the REDD+ architecture, four basic building blocks are being discussed under the UNFCCC, namely scope, reference levels, financing and distribution.

\section{Scope}

First of all, the scope refers to what types of emissions-reduction activities are covered by REDD+. ${ }^{73}$ As far as the scope of REDD+ is concerned, it seems clear as stated in the Cancun Agreement, the most current decision of the UNFCCC, that REDD+ covers the following activities: (1) reducing emissions from deforestation; (2) reducing emission from forest degradation; (3) conservation; (4) sustainable management of forests; and (5) enhancement of forest carbon stocks. The accommodation of such activities seems to be "an important compromise reached between those who wanted REDD+ to be solely about deforestation and those who want it to expand to other land uses"74 for example Agriculture, Forestry and Other Land Uses (AFOLU). Bolivia even went further to propose deletion of words 'emissions reduction' and proposing "reducing deforestation and forest degradation" instead, as Bolivia concerned that forest carbon would be the overriding interests in protecting forests while ignoring other values of them. Bolivia's proposal was, however, rejected by other parties in COP 16 Cancun. $^{75}$

In relation to the scope, definitional issues are essential to determine the eligible activities in achieving the REDD+ effectiveness, efficiency, equity and co-benefit $(3 \mathrm{E}+)$. In fact, in the context of REDD+, definitions of 'forest', and 'deforestation' are very important but until now no agreement reached on these matters. ${ }^{76}$ While the Decision 16/CMP.1 on LULUCF rules under the Kyoto Protocol agree to adopt previous decisions with regard to definitions, modalities, and guidelines for the post-2012 LULUCF activities ${ }^{77}$, it remains unclear whether or not the LULUCF rules on definitional issues would be transferred directly to the REDD+ scheme. This is due to inconclusive relation between the Kyoto Protocol and the future of REDD+. If the definitions from LULUCF rules were transferred to REDD+, new problems would occurred in REDD+ implementation. 'Forest', for instance, under the LULUCF rules, is defined as

"a minimum area of land of 0.05-1.0 hectares with tree crown cover (or equivalent stocking level) of more than 10-30 per cent with trees with the potential to reach a minimum height of 2-5 meters at maturity in situ. A forest may consist either of closed forest formations where trees of various

${ }^{72}$ Chris Lang, (2011). Why REDD+ is Dangerous. Available at <http://www.redd-monitor. org/2011/02/05/why-redd-is-dangerous-in-its-current-form/>

${ }^{73}$ C. Parker, Op.cit., p. 20

${ }^{74}$ A. La Vina, (2010). The Future of REDD-Plus: Pathways of Convergence for the UNFCCC Negotiations and the Partnership, p.7

${ }^{75}$ Ibid., p. 15-16

${ }^{76}$ Chris Lang, Op.Cit., p.77

77 See Decision 16/CMP 1, FCCC/CMP/2005/8/Add.3, para.4 
storeys and undergrowth cover a high proportion of the ground or open forest. Young natural stands and all plantations which have yet to reach a crown density of 10-30 per cent of tree height of 2-5 meters are included under forest, as are areas normally forming part of the forest area which are temporarily unstocked as a result of human intervention such as harvesting or natural causes but which are expected to revert to forest"78 (emphasis added)

Definition of forest above seems merely based on a quantitative perspective. In fact, this would deny a qualitative perspective of forest that refers to biodiversity 'within species, between species and of ecosystem, ${ }^{79}$ upon which resilience in providing ecosystem services depends. If REDD+ focuses on the quantitative definition of forest, it may encourage conversion of forest into monoculture and commercial tree plantation. As a result, this may risk biodiversity and increase 'inter-ecosystem leakage' that is "increased pressure on non-forest ecosystems with high relevance for biodiversity conservation caused by a successful reduction of deforestation".80 In addition, defining and measuring 'forest degradation' are not less straightforward in this regard. This is why the inclusion of 'forest degradation' into RED initiative was contentious for some countries although they finally agreed to include it as a compromise.

Moreover, the inclusion of SMF and 'enhancement of forest carbon stocks' is also controversial due to their multiple interpretations. 'Sustainable management of forests' (SMF) is interchangeable with 'sustainable forest management' (SFM), in which the latter is rather a controversial term in the context of operation of logging or plantation companies since they have been unable to manage forest in sustainable manner, and even have created conflicts within indigenous territories ${ }^{81}$. On top of that, both sustainable forest management and enhancement of forest carbon stocks activities are argued to have negative impacts on biodiversity due to their unclear criteria. ${ }^{82}$ Therefore, the scope of REDD+ designed so far appears difficult to generate co-benefit, and to be effective and equitable, since the scope arguably opens loopholes and is problematic even at the basic definitional levels.

\section{Reference Levels}

The reference level refers to periods or scales against which emissionreduction will be measured. Reference levels or baselines, however, may mean two things; firstly, reference levels or baseline may refer to a prediction about the possible outcome if REDD+ is not undertaken or "business-as-usual" (BAU) scenario, or as the "benchmark for measuring the effect of a REDD+ intervention"; secondly, it may be interpreted as a baseline for crediting REDD+ activities, or as

\footnotetext{
${ }^{78}$ Marrakesh Accords, FCCC/CP/2001/13/Add.1, Annex, para.1 (a), 58

${ }^{79}$ Article 2(1) of the 1992 Convention Biological Diversity

${ }^{80}$ T. Pistorius, C. Schmitt, D. Benick, and E. Entenmann, (2010). Greening REDD+: Challenges and Opportunities for Forest Biodiversity Conservation, p.1

${ }^{81}$ See Carrere, R. (n.d) A Critical Vision of REDD' in No REDD. Ed.by. J. Cabello and T. Gilberston. Mexico: Carbon Trade Watch and Indigenous Environmental Network. p.53; see also Peskett, L., and Yanda, P. (2009). The REDD+ Outlook: How Different Interests Shape the Future. London: Overseas Development Institute, London. p.4

${ }^{82}$ T. Pistorius. et al, Op.cit., p. 4
} 
the 'benchmark' for incentives for a REDD+ carbon right holder. ${ }^{83}$ In this regard, there are three options on the table such as a 'historical baseline', a 'historical adjusted baseline', and a 'projected baseline'. Furthermore, each option should be measured against three optional scales, namely 'sub-national', 'national', and 'global' scales. ${ }^{84}$

The historical baseline refers to the idea that a proxy for future deforestation behavior is based on its past rates of deforestation. However, the historical baseline requires data on deforestation rates in which such data is difficult to obtain if not unavailable in many developing countries, and the historical baseline does not take changing in circumstances time to time into account ${ }^{85}$ In order to respond to the weaknesses of the historical baselines, the projected baselines have been proposed by parties. The projected baselines are based on prediction of deforestation rates in the future that may use various methods of measurements, for example by using econometric to analyze the underlying socio-economic or structural pressures leading to deforestation.The biggest concern for the projected baselines is to decide the accurate variables that are likely to be the most significant drivers of deforestation in a country. Another approach is the historical adjusted baseline based on combination between 'pure historical baseline and projected baseline'. Using a Development Adjusted Factor (DAF) to be applied to the historical baseline, it is expected that the future drivers of deforestation could be predicted. ${ }^{86}$ However, until now, no agreement has reached on how to set a reference level among experts ${ }^{87}$, while every participating country or project developer uses its own references in developing REDD+ demonstration projects.

Furthermore, reference levels should be connected to the scale of REDD+. In this regard, at least there are three approaches put on the table. The first one is a national approach based on a national baseline or reference scenario. ${ }^{88}$ The second is sub-national approach based on project-based reference levels or baseline and this would operate under similar modalities to CDM projects. ${ }^{89}$ The sub-national approach is chosen because it allows a developing country that has no capacity to establish national carbon accounting systems, and is more attractive for private sectors since they could directly monitor the project. Finally, a 'nested approach' is being proposed to provide incentive for REDD+ activities at both sub-national and national levels. Under this approach, a country may start a reference level from a sub-national scale, which will then be scaled up into a national level for the next stage simultaneously with building its capacity to develop national carbon accounting systems. ${ }^{90}$

The main concerns of such approaches are their possibility of leakage and problems regarding additionality and permanence. Leakage is "a situation in which deforestation avoided in one area results in deforestation in another, whether within or between countries, which could severely undermine the

${ }^{83}$ L. Verchot and A. Angelsen, (2009). Box 7.2. Monitoring and Establishing Reference Levels in Realising REDD+: National Strategy and Policy Options. Ed.by. Arild Angelsen, p.90

${ }^{84}$ C. Parker. et al., Op.cit., p. 21

${ }^{85}$ Ibid.

${ }^{86}$ Ibid.

${ }^{87}$ L. Verchot and A. Angelsen, Op.cit., p.90

${ }^{88}$ Ian Fry, (2008). Reducing Emissions from Deforestation and Forest Degradation: Opportunities and Pitfalls in Developing a New Legal Regime.17 RECIEL.p.169

${ }^{89}$ Ibid., p.169-170

${ }^{90}$ C. Parker. et al., Op.cit., p.84 
effectiveness of REDD". ${ }^{91}$ Leakage can be differentiated into two main categories such as: (1) 'activity shifting' as the case when an activity displaces from one area to another as a result of REDD+ implementation in such area; (2) 'indirect market leakage' when leakage occurs due to the 'market law of supply and demand'. ${ }^{92}$

In terms of additionality, REDD+ shall be able to reduce emissions from DD greater than business-as-usual scenario. Closely linked to additionality, permanence requires REDD+ activities to maintain carbon forest stocks in trees over time. With regard to a non-performing REDD+ project, in fact, many solutions have been proposed to compensate the loss arising from the failure of a REDD+ project to address leakage, permanence and additionality once credits have been distributed. The proposed solutions include insurance policies, shared liability, temporary crediting, long-term accounting, etc. ${ }^{93}$

However, if leakage cannot be addressed, additionality and permanence is lacking, REDD+ will become the part of the climate problem. A failed REDD+ mechanism, instead of achieving the ultimate objectives of the UNFCCC, would reverse the situation as it may provide pseudo solution to make parties continually emitting emissions without felling guilty to do so. This tendency has been shown by at least 20 percent of CDM projects in which additionality of such projects was miscalculated. ${ }^{94}$

Potential international leakage also has evidently occurred. For example, it is likely that major palm oil companies in Indonesia plan to move to African countries due to Indonesia's policy on a 2-year moratorium for forest conversion as a result of national policy on REDD.$+^{95}$ Moreover, a wide range of options to compensate the (economic) loss would not be able to compensate GHG emitted to the atmosphere by the failure of non-performing projects. As a result, the earth's temperature would continue to increase and the impacts of climate change would even be worse. Therefore, a failed REDD+ mechanism is possible to be a distraction for parties to delay taking actions timely with real solutions to climate change.

\section{Financing and Distribution}

One of the most controversial building blocks, arguably, is financing and distribution. Financing in this context refers to the sources of finance as direct revenue to provide incentive for an emission-reduction activity under the REDD+ scheme; meanwhile, distribution refers to options in distributing or allocating benefits as financial incentives to countries that maintain their forests standing despite the fact that they are not directly participating in REDD+ activities. ${ }^{96}$ Indeed, the purpose of a distribution mechanism is to address concerns on equity of REDD+. More importantly, it is to avoid international leakage that is moving deforestation from a country with REDD+ activities to another country without REDD+ activities. The argument is that if a High Forest Cover, Low

\footnotetext{
${ }^{91}$ M. Hufty and A. Haakenstad, Op.cit., p.5

${ }^{92}$ J. Ebeling, Op.cit., p. 50

${ }_{93}$ M. Hufty and A. Haakenstad, Op.cit.

${ }^{94}$ D. Takacs, (2009). "Carbon into Gold: Forest Carbon Offsets, Climate Change Adaptation and International Law”. 15 Hastings W.Nw. J. Envt'l L. \&Pol'y, 2009. p.58

${ }^{95}$ Ecologist, (2011) http://www.theecologist.org/News/news_analysis/823928/pa[accessed 26

${ }^{96}$ C. Parker. et al., Op.cit., p. 24
} March 2011] 
Deforestation Rates (HFDL) ${ }^{97}$ country is not rewarded in protecting its forest carbon stocks, the country will be likely to deforest for more profitable revenues when demands on forest products in global market increase. ${ }^{98}$

There are several options in financing REDD+, namely 'carbon market', 'market-linked', 'voluntary', and the 'phased approach'. First of all, REDD+ under carbon market schemes would issue a credit similar to a CER under the CDM, in which such credit could be counted in meeting emissions reduction or compliance targets..$^{99}$ Secondly, REDD+ activities could also generate sources of finance from various mechanisms under a market-linked approach, for example auction of emissions allowances. Although emission reduction is not their main objective, if they are able to reduce emissions, the amount of reduction may be counted to meet emission-reduction targets. ${ }^{100}$ Finally, REDD+ under a voluntary funding mechanism could generate sources of finance through Official Development Assistance (ODA) and other bilateral and multilateral sources. In fact, the key element under such a mechanism is that emissions reduced by REDD+ activities cannot be counted toward meeting compliance targets. ${ }^{101}$

Alternatively, under the 'phased approach' REDD+ mechanism is divided into 3 phases, namely 'Readiness', 'More Advance Readiness', and 'Compliance' phases. ${ }^{102}$ Thus, the sources of finance are generated depending on which phase of a REDD+ activity is taking place. A voluntary funding mechanism, for instance, is more suitable for the Readiness phase in which capacity building and demonstration activities are being developed. ${ }^{103}$ A REDD+ activity in the Advance Readiness in which scaling up REDD+ activities are taking place is argued to be more appropriate to use market-linked approach, for example from the auctioning of carbon allowances. ${ }^{104}$ In fact, REDD+ under the compliance phase is argued to be likely to generate sources of finance from both carbon market and market-linked mechanisms since under this phase more consistent and long-terms financial sources are needed. ${ }^{105}$

However, the proposal to use carbon market as the financial source of REDD+ seems highly controversial for some reasons. A study conducted by the Centre for European Economic Research in 2008 concluded that integration of REDD+ into existing carbon market could decrease the price of international carbon permit by half because a REDD + credit supplied from tropical rainforest regions is cheaper. ${ }^{106}$ Moreover, an estimation from the Eliasch Review indicates that although an annual cost of US\$17-33 billion is needed for halving forestrelated emissions by 2030 , only US $\$ 70$ billion by 2020 can be provided by

${ }^{97}$ The Forest Transitional Theory which classifies forested countries into five stages, namely (1) High Forest Cover, Low Deforestation Rates (HFLD); (2) High Forest Cover, High Deforestation Rates (HFHD); (3) Low Forest Cover, High Deforestation Rates (LFHD); (4) Low Forest Cover, Low Deforestation Rates (LFLD); and, (5) Low Forest Cover, Negative Deforestation Rates. See Angelsen, A. supra note 14.p.4

${ }^{98}$ C. Parker. et al., Op.cit.

${ }^{99}$ Ibid., p.26

${ }^{100}$ Ibid.

101 Ibid.

${ }^{102}$ S. Wertz-Kanounnikoffand A. Angelsen, (2009). Global and National REDD+Architecture: Linking Institutions and Actions in Realising REDD+: National Strategy and Policy Options. Ed.by. ArildAngelsen. Denmark: CIFOR, p.15

${ }^{103}$ C. Parker. et al., Op.cit. p.92

${ }^{104}$ Ibid.

105 Ibid.

106 N. Angerand J. Sathaye, (2008). Reducing Deforestation and Trading Emissions: Economic Implications for the Post-Kyoto Carbon Market, p. 23 
carbon market schemes. ${ }^{107}$ Thus, public fund will still be required because market cannot provide enough financial sources.

Moreover, carbon market is a very complex system in which the carbon price is also fluctuating. When the price goes drop, indigenous peoples and local communities who have given up their livelihood to be set as a REDD+ project would be under serious threats of becoming the victim for the second times due to inadequate payments after losing their livelihood. ${ }^{108}$

With regard to the building block on distribution, there are two options being proposed, namely a 'redistribution mechanism' or an 'additional mechanism'. Firstly, the redistribution mechanism is based on a global baseline that allocate revenues to the High Forest Cover, Low Deforestation Rate (HFLD) countries with deforestation rates below the global average. ${ }^{109}$ Secondly, the additional mechanism uses additional funding from various sources in avoiding international leakage and addressing equity between HFDL countries. ${ }^{110}$ Several possible sources are including 'voluntary fund' or 'innovative finance mechanisms' such as levies on aviation and shipping or the auctioning of allowances. However, at the local levels, distribution may raise several problems regarding which parties are the most appropriate one to receive such incentives. Indeed, distribution is closely linked to the carbon right holder that is determined by the owner of the forests concerned. In many cases, local communities and indigenous peoples often have no title or land right over forest they live in; thus, it seems unlikely that they would be the beneficiaries under these distributional schemes.

\section{REDD+ in Indonesia}

\section{A. The National REDD+ Architecture}

Diverse architectures of REDD+ are being designed on the ground. This reflects different circumstances of developing countries as well as national expectation to the future REDD+ scheme. According to UN-REDD, there are more than hundreds REDD+ projects as a part of learning process for establishing an international REDD+ scheme. In Indonesia alone, the REDD+ architectures are designed through demonstration projects that have spread out the country since 2007 [15 projects in Borneo, 10 projects in Sumatera, 2 in Java, 3 in Sulawesi and 5 projects in Papua] with various size of each project ranging from 10,000 ha to 4.2 million ha. ${ }^{111}$ In analysing critically the extent to which such architectures are able to contribute to the objectives of REDD+, this section discusses REDD+ in Indonesia by focusing on its model, related laws and policies, institutional arrangements, as well as safeguards and co-benefits.

\section{Indonesia, Climate Change and Deforestation}

Indonesia is an archipelagic country consisted of more than 17,000 islands with an area of 2 million square $\mathrm{km}$ and population at around 238 million people

\footnotetext{
${ }^{107}$ A. La Vina, Op.Cit., p.9

${ }^{108}$ T. Mannand T. Surya, (2009). REDD Wrong Path: Pathetic Ecobusiness. Jakarta: WALHI, p.20

${ }^{109}$ C. Parker. et al., Op.cit., p.24

${ }^{110}$ Ibid., p.25

${ }^{111}$ E. Sills, et al., (2009). The Evolving Landscape of REDD+ Projects in Realising REDD+: National Strategy and Policy Options. Ed.by Arild Angelsen. Denmark: CIFOR, Denmark, 274
} 
across 33 provinces, and they are diverse in culture and ethnicities. ${ }^{112}$ In forestry issues, the Food and Agriculture Organisation (FAO) considers Indonesia as a country among other ten most rapid deforested countries in which during 20052010 it was estimated that forest cover declined about 3.42 million ha, and during 1990-2010 it declined by 24.1 million ha. ${ }^{113}$ Indonesia is also regarded as the largest GHG emitter from land use, LULUCF. ${ }^{114}$ As an archipelago, in fact, Indonesia is one of the most vulnerable countries from the impacts of climate change particularly rising in sea levels and it is predicted that around 3,000 islands would be under water. ${ }^{115}$

Globally, deforestation rates and land-use change are at 6 million ha every year. If this pattern continues, it is predicted that around $15 \%$ of remaining forests would be lost by 2015, and around $70 \%$ of them would disappear by the next two hundreds years. ${ }^{116}$ In the climate change context, the remaining forests are estimated to store around $638 \mathrm{GtC}$ in which around $283 \mathrm{GtC}$ of them is forests biomass. This amount of carbon stored by forests is significantly huge and more than carbon in the atmosphere. ${ }^{117}$ Deforestation on dry land and peat swamps during 2000-2005 was estimated to emit up to 2.479 million tCO2e and if the additional peat fires was counted, the amount raised up to 502 million tCO2e. ${ }^{118}$ In Indonesia alone, while Indonesia's forests contain around 13,143-25,547 MtCO2 forest carbon stocks, carbon emissions from DD are calculated approximately 55 MtC02e. ${ }^{119}$ According to the FAO's 2005 Forest Report Assessment, the rate of deforestation in Indonesia is estimated around 1.9 million ha annually in which dry land forests and peat swamps as two most significant sources. Borneo (Kalimantan) and Sumatera are the biggest emitters of GHG from deforestation with estimation of 84\% of Indonesia's total emissions from LULUCF. ${ }^{120}$ Based on historical data, the deforestation rate in Indonesia is projected to be 1.125 million ha annually. ${ }^{121}$

The complex forest governance has become one of the most important issues in Indonesia. Forests in Indonesia so called 'state forests' are managed into four categories, namely production forest, protection forest, conservation forest and conversion forest. During period of 1965-2001, the Ministry of Forestry had an exclusive authority to manage forestry sectors. However, since the era of decentralisation in 2001, there has been a delegation of responsibility and decision-making authority to districts level, although the Ministry remains powerful in deciding a status of state forests. In fact, such delegation in many

\footnotetext{
${ }^{112}$ See <http://www.nationsonline.org/oneworld/indonesia.htm> [accessed 20 August 2011]

${ }^{113}$ J. Blaser, et al., (2011). ITTO Technical Series No. 38: Status of Tropical Forest Management 2011. Yokohama, Japan: International Tropical Timber Organization, Yokohama, p.181

${ }^{114}$ Peace,et al., (2007). Indonesia and Climate Change: Current Status and Policies. Jakarta: Peace, p.15

115 See <http://seagrass-indonesia.oseanografi.lipi.go.id/en/news/36-3000-pulau-indonesiaakan-tenggelam.html>

${ }^{116}$ R. O'Sullivan, (2008). Reducing Emissions from Deforestation in Developing Countries: An Introduction' in Climate Change and Forests: Emerging Policy and Market Opportunities. Ed.by. C. Streck et al. London: Royal Institute of International Affairs, p.179

117 Ibid.

118 NORAD, (2010). Real-Time Evaluation of Norway's International Climate Forest Initiative: Contribution to National REDD+ Processes 2007-2010. Oslo: Norad, p.34

${ }^{119}$ J. Blaser, et al., Op.Cit., p.190

${ }^{120}$ NORAD, Op.Cit., p. 20

${ }^{121}$ Government of Indonesia, (2010). Draft National REDD+ Strategy. Jakarta: GoI and UN-REDD, 
cases opens a vacuum of forest governance benefitting local elites, companies and illegal loggers. Instead of encouraging forest management in sustainable manner and good governance, many governments at district levels have used forests for generating revenue and maintaining the culture of corruption. ${ }^{122} \mathrm{On}$ the other hand, state forests that cover more than $70 \%$ of the total Indonesian terrestrial areas are inhabited by 40 - 65 million people. According to the Ministry of Forestry, these people do not have title of ownership so that a permit issued by the Ministry is required if they want to use forest areas. ${ }^{123}$

In terms of drivers of deforestation in Indonesia, the Government of Indonesia (GoI) devides them into two categories. The first category is planned drivers that include palm oil plantation as well as pulp and paper concession up to 10 million since 2007; and, community timber plantation up to 5.4 million ha by $2016 .{ }^{124}$ In fact, by 2008, fast growing tree plantation covered around $2 \%$ of the total land area in Indonesia or around 4.3 million ha. In many instances the plantation was subsidised by government spending and received extra economic benefits from timber clearance revenue when opening forests for the plantation. ${ }^{125}$ Palm oil plantations, which also receive similar benefits, have expanded more than 40 times since 1967, and in 2010 it was estimated that they covered $4 \%$ of the total Indonesia's land area or around 7.3 million ha. ${ }^{126}$ The second category is unplanned drivers, which include illegal logging both large and small scales, lack of monitoring capacity, unsustainable practices in managing forest and etc. ${ }^{127}$

\section{REDD+ Related Law and Policies}

Prior REDD+ rapid development, Indonesia has had several legal and policy frameworks on forest protection. Despite the fact that they do not specifically have objectives to cut GHG emissions, they seem relevant to the forest carbon context, among others: Presidential Decree No.32/1990 prohibiting development on peat with more than 3 meters deep; Government Regulation PP No.4/2001 prohibiting the use of fire in forestry activities; Ministerial Decree SK 159/Menhut-II/2004 on the restoration of degraded ecosystem within production forests; Presidential Instruction No. 4/2005 on illegal logging; Government Regulation PP No.6/2006 on forest management and utilisation; Ministerial Decree No.260/1995 on Guidelines for Fire Control and Prevention; Law No.41/1999 on Forestry and Law No.5/1990 on Biological Diversity Conservation.

Development of REDD in Indonesia could be dated back shortly before COP 13 Bali, Indonesia, in December 2007. In the late 2006, the Government of Indonesia (GoI) established the Indonesia Forest Carbon Alliance [IFCA], a working group to assess and assist Indonesia in reducing emissions from forestry sectors in which after COP 13, the IFCA was able to publish a report called the IFCA Consolidation Report and becoming a reference work on REDD in Indonesia. ${ }^{128}$ Moreover, an announcement of President Yudhoyono during

\footnotetext{
${ }^{122}$ NORAD, Op.Cit., p.17-18

${ }^{123}$ Ibid., p.14

${ }^{124}$ Government of Indonesia, (2010). Op.Cit, p.41; NORAD, Op.Cit., p.37

${ }^{125}$ NORAD, Op.Cit., p.16

${ }^{126}$ Ibid.

${ }^{127}$ Government of Indonesia, (2010). Op.Cit, p.41

${ }^{128}$ NORAD, Op.Cit., p.19
} 
the G20 Meeting in 2009 that Indonesia committed to reduce its domestic emissions by $26 \%$ below Business as Usual (BAU) scenario by 2020 , or $41 \%$ below BAU with international supports has become one of the most influential factors in this regard. ${ }^{129}$ As the first commitment made by a developing country, the announcement has pushed all the governments' sectors in Indonesia to undertake climate change programmes seriously, to compile such programmes to the Indonesian Climate Change Sectoral Road Map ${ }^{130}$, and to integrate them into a Long-term National Development Plan 2005-2025. ${ }^{131}$

The Indonesian Ministry of Forestry has responded by establishing framework to control the process of REDD development, and to regulate its implementation through policies and decrees as well as institutional arrangements. There are two important policies have been issued by the Ministry, namely a Regulation No. P.68/Menhut-II/2008 on the regulation on the implementation of REDD demonstration activities and SK/455/Menhut-II/2008 on the establishment of a Ministry of Forestry's Working Group on Climate Change. Moreover, the Ministry has issued additional policies such as: a Regulation No. P.30/Menhut-II/2009 in regulating the implementation of REDD which includes developers' obligations, verification and certification, and terms of conditions; and, a Regulation No. P.36/Menhut-II/2009 on the permissions procedures for carbon sequestration and/or carbon storage projects in production forests and protection forests, as well as a scheme on sharing revenue arising from such projects among developers, communities and governments.

Other progresses have also been made domestically. In the MediumTerm Plan of the Ministry of Forestry, several priorities set up in addressing challenges to tackle DD. Some of them are: securing forest areas by strengthening their boundaries; undertaking degraded forest rehabilitation; protecting and managing forest from forest fire; conserving biodiversity; revitalising the use of forest and industries; empowering indigenous peoples and local communities; and strengthening institutions. ${ }^{132}$

The GoI has also released provisions related to climate change in its new law on environmental protection and management, Law No.32/2009. In Article 63 , it requires national and district governments to develop GHG inventories and take necessary policies on climate change.

In addition, Indonesia has also published a REDD+ Readiness Plan [R-Plan]. One of its features is focused on emission reduction from palm oil plantation, strategic plans in pulp plantation, productions forests and peat lands. In general, all progress made by Indonesia is argued as the first national legal regime in the world for implementing REDD. ${ }^{133}$

However, the R-Plan could be criticised. Firstly, the R-Plan has no specific strategy to reduce emissions from protected areas, and fails to address the causes of DD outside the forestry sectors. ${ }^{134}$ Secondly, although one of the objectives of the R-Plan is applying a 'nationwide system of good governance level by 2008', no evidence shows that the objective has been met. The Plan has no strategy to reduce illegal activities such as illegal logging or corruption. In fact, corruption

\footnotetext{
${ }^{129}$ Government of Indonesia, (2010). Op.Cit, p.24

${ }^{130}$ NORAD, Op.Cit., p. 20

${ }^{131}$ Government of Indonesia, (2010). Op.Cit, p.36

132 NORAD, Op.Cit., p.51

${ }^{133}$ Ibid.

${ }^{134}$ Ibid., p.52
} 
is widespread due to the absence of effective mechanisms, lack accountability and patronage culture. These causes of illegal activities and corruption should be eliminated to make REDD+ in Indonesia effective. ${ }^{135}$ Neither does the Plan discuss the importance of independent monitoring in the Monitoring, Reporting and Verification (MRV) procedure, which is essential to provide objective evaluation.

The progress on developing legal and policy framework does not mean that the problems of DD have been addressed effectively. It is frequently argued that DD in Indonesia has nothing to do with the legal and policy framework, but has a great deal to do with the implementation of such framework. In fact, a study conducted by Arnold shows different result by arguing that numerous laws and policies do encourage deforestation or opens loopholes in the implementation of forest protection. One example is the Regional Autonomy Law No.24/2004 which provides unclear delegation of power from the central government (the Ministry of Forestry) to district governments. ${ }^{136}$ The study also concludes that the Regional Autonomy Law fails to encourage integrated approaches within government sectors in managing forests and is lacking the mechanisms of public participation, particularly with respect to access to information, decisionmaking and justice. ${ }^{137}$

\section{Institutional Arrangements}

Institutions play a vital role in pursuing the objectives of REDD+. The most important dilemma regarding institutions in the context of REDD+ is that whether creating completely new institutions is necessary or whether the existing institutions are adequate to implement REDD+. Establishing new institutions requires a long period of time to settle with adequate management and coordination across sectors and stakeholder groups. This attempt is also politically challenging due to resistance from the existing government institutions; however, maintaining the existing institutions would lead to 'business as usual mindset and practices.' ${ }^{138}$ A 'one size fits all' approach does not seem to be the solution since the best solution would depend upon national circumstances. In the context of REDD+ in Indonesia, thus, the chosen strategy is the creation of new institutions, namely the National Council on Climate Change and the REDD+ Task Force.

It is argued that the National Council on Climate Change (NCCC or Dewan Nasional Perubahan Iklim) is the most important institution in the context of climate change at national levels. The Council was established in July 2008 by a President Decree No.46/2008. It has main tasks as a body to co-ordinate and monitor the implementation of climate change action plans, and to conduct a meeting at least quarterly. There are six working groups created within the Council, namely Adaptation Working Unit; Mitigation Working Unit; Transfer of Technology Working Unit; Funding Working Unit; Post-Kyoto 2012 Working Unit; and, Forestry and Land Use Conversion Working Unit in which REDD+ is discussed. Members of the working units consist of government officers and NGO delegates, and they meet monthly. However, as a 'para-governmental

\footnotetext{
${ }^{135}$ Ibid., p.60

${ }^{136}$ Ibid., pp. 28-29

${ }^{137}$ Ibid.

${ }^{138}$ F. Seymourand A. Angelsen, (2009). Op.Cit., p.294-295
} 
organisation', the legal status of the NCCC remains so unclear that it faces difficulties in undertaking its mandates effectively, especially in coordinating with government departments. In addition, it has also been argued that the Council is in fact underfunded. ${ }^{139}$

Specifically on REDD+, a Presidential Delivery Unit for Supervision and Monitoring Development (UKP4/REDD+ Task Force) has been established. The REDD+ Task Force was appointed by President Yudhoyono shortly after announcing a bilateral partnership on forest carbon between Indonesia and Norway [Letter of Intent/LoI] in 2010. The Task Force consists of three independent working groups focusing on institutional issues, financial issues, and MRV issues. However, some criticise the leadership of the REDD+ Task Force for being incompetence and lacking commitment to bring about effective coordination with relevant government's bodies, as the members appointed based on political connection to President rather than based on expertise. ${ }^{140}$ The REDD+ Task Force appears to be overlapped to the NCCC both structurally and personally due to unclear job descriptions given by REDD+ policies, and the fact that some members of the NCCC are also members of the REDD+ Task Force ${ }^{141}$

In order to gain support from international community in its effort to pursue low carbon economy as well as adaption to climate change, the Government has created two funding institutions. The first one is the Indonesian Climate Change Trust Fund (ICCTF) that was established by the NCCC in 2008. The ICCTF is expected to raise fund for adaptation and mitigation programmes, with three 'priority windows', namely 'energy and energy efficiency', 'sustainable forestry and peat land management'; and resilience'. ${ }^{142}$ However, until now only few donors have contributed to the ICCTF. ${ }^{143}$ Thus, the effects of such fund seem to be insignificant. The second institution is the Indonesian Green Investment Fund (IGIF) managed under the Ministry of Finance, in particular the Government Investment Unit (GIU). Its main objective is "to leverage private and market-based funding for low emissions development programmes or projects". It has operated since 2010 with preliminary investment of US $\$ 100$ million from the GIU itself. It is expected that within 5 years, the IGIF would have raised investment up to US\$5 billion. ${ }^{144}$

The institutions established to manage REDD+ above are faced not only with a complicated REDD+ methodology, MRV, and safeguards, but also with acute domestic challenges, namely poor forest governance and corruption. These acute problems should be addressed since they are essential to determine the successful of REDD+ in delivering effectiveness, efficient, equity and cobenefits as expected. In fact, in Indonesia, weak forest governance is argued to be responsible for widespread illegal logging which causes about $73-88 \%$ of total deforestation, and costs loss of revenues approximately Rp.30 trillion (US\$3billion) per year. ${ }^{145}$

\footnotetext{
${ }^{139}$ NORAD, Op.Cit., p.49

${ }^{140}$ Ibid., p.50

${ }^{141}$ SeeTheJakartaPost(2010)24September<http://www.thejakartapost.com/news/2010/09/24/ kuntoro-mangkusubroto-chairs-redd-task-force.html> [accessed 14 August 2011]

${ }^{142}$ See <http://www.climatefundsupdate.org/listing/icctf> [accessed 14 August 2011]

${ }^{143}$ NORAD, Op.Cit.

144 Ibid.

${ }^{145}$ T. Mannand T. Surya, (2009). Op.Cit., p.45
} 
In this regard, the next question would be if a country cannot police logging, would it be able to police not logging? ${ }^{146}$ Indeed, as a large amount of money will be injected in REDD+ mechanisms, this may be a new avenue for corruption among government officials and local elites if the pattern of corruption is not addressed effectively. ${ }^{147}$

\section{Partnership and The First Generation of REDD+ Project}

The Indonesian Government has been involved in partnership programmes with several countries, private sectors, financial institutions, as well as NGOs. In 2007, Indonesia and Germany agreed to an agreement so called the Forest and Climate Change Programme (FORCLIME) with three main components such as: national level policy, strategy and instruments; provincial level support for REDD demonstration activities; project level support for nature conservation and sustainable development in the 'Heart of Borneo'. ${ }^{48}$ The US Government through USAID has also supported the Government with a programme called 'Tropical Forest Conservation Action Debt for Nature' to redirect a US $\$ 22$ million Indonesian debt to be used in conservation projects in Sumatera and Borneo. ${ }^{149}$ In 2008, the Indonesian and the Australian Governments agreed to a US\$40 million programme called the Indonesia-Australia Kalimantan Forest Carbon Partnership (KFCP) with three main areas such as: (i) policy development and capacity building to support participation in international negotiations and future carbon markets; (iii) technical supports for Indonesia in developing national forest carbon accounting and MRV systems; and (iii) further development of demonstration activities, and the provision of related enabling assistance to trial approaches for REDD. ${ }^{150}$

The NCCC, particularly its working group on forestry and land use conversion, has started to work multilaterally in developing the national REDD+ architecture with the UN-REDD and the Forest Carbon Partnership Facility (FCPF) of the World Bank. ${ }^{151}$ However, both the FCPF and UN-REDD have been criticised by NGOs and indigenous groups because their lack of public participation. ${ }^{152}$

In addition, several concerns have been raised on the FCPF project, such as: (1) neglecting the mandate of the World Bank in reducing poverty by focusing its programme on forest carbon; (2) supporting carbon market that may risk the forest governance to be taken over by commercial carbon market interests; (3) lacking application of the Bank's social and environmental safeguards, and in respecting indigenous peoples' rights. ${ }^{153}$ As a result, the FCPF is urged to conduct an environmental and social impacts and risks assessment. ${ }^{154}$

Another important partnership for REDD+ in Indonesia is the bilateral agreement between Indonesia and Norway. The agreement known as the Letter of Intent (LoI) on "Cooperation on Reducing Greenhouse Gas Emissions from

\footnotetext{
${ }^{146}$ Ian Fry, (2008). Op.Cit., p.175

${ }^{147}$ T. Mannand T. Surya, (2009). Op.Cit., p.46

${ }^{148}$ NORAD, Op.Cit., p.30

${ }^{149}$ Ibid., p.59

${ }^{150}$ Ibid.

${ }^{151}$ Ibid., p. 19

${ }^{152}$ See Ibid., p.54-55; see also T. Griffiths, (2008). Op.Cit., p.10

153 Ibid., p.38

${ }^{154}$ K. Dooly, T. Griffiths, F. Martone, \& S. Oziga, (2011). Smoke and Mirrors: A Critical Assessment of the Forest Carbon Partnership Facility. Brussel: FERN and Forest Peoples Programme, p. 35
} 
Deforestation and Forest Degradation" aims at conducting policy dialogue and supporting the development of REDD+ strategy in Indonesia. ${ }^{155}$ Many argue that the strong support of Norway in this context is related to its ambition to be 'carbon neutral' by 2030 . While $2 / 3$ of its reduction taking place domestically, the rest will be met through carbon offsets abroad. ${ }^{156}$ This appears controversial for many observers since Norway is a major exporter of fossil fuels which largely contributes to global emissions. ${ }^{157}$ In pursuing such ambition, Norway put a two-year moratorium on natural forest and peatland conversion in Indonesia as one of the items in the LoI ${ }^{158}$, and it has been implemented by a Presidential Instruction No.10/2011 since 19 May 2011. An investigation conducted by Telapak and the Environmental Investigation Agency (EIA), however, finds that the moratorium has limited impacts in practice as the Instruction opens loopholes and only covers primary forests that has already been protected under Forestry Law as protected forest; thus, encroachment of secondary forests has continued from the first day of moratorium. ${ }^{159}$

As far as REDD+ projects in Indonesia are concerned, the UluMasen Project, represented the first generation of REDD, can be used as a benchmark in designing the future REDD+ projects. According to its Project Design Note (PDN) submitted in 2007 by the Provincial Government of Aceh in collaboration with Carbon Conservation, an Australian carbon-trading firm, and the Fauna \& Flora International (FFI), the Project covers around 750,000 ha of forest in the UluMasen ecosystem. It is expected to reduce $85 \%$ of deforestation in the area similar to avoiding around 3.3 million tCO 2 emitted every year. ${ }^{160}$ A US\$9 million financial support has been agreed by US Bank Marrill Lynch for 4 years with an expectation to generate US $\$ 432$ million by the next 30 years through voluntary carbon market (Mann and Surya 2009:65). ${ }^{161}$ There are around 130,000 people who live in 61 mukim (villages) within the project area affected by project activities including reforestation, forest monitoring, and land-use planning and reclassification. ${ }^{162}$

Regarding the project, some issues have been raised concerning representation, dispute resolution, and forest protection procedure. Firstly, the project is criticised due to unclear implementation of the principle of Free, Prior, and Informed Consent (FPIC) and lack of participation despite the principle and public participation being stated with a strong language in the Project Design Note. $^{163}$

In addition, in developing mechanisms for benefit distribution, the project requires a 'collaborative stakeholder dialogue' to include indigenous peoples, local communities and NGOs to participate fully and actively. ${ }^{164}$ However,

${ }^{155}$ Letter of Intent (LoI) Norway-Indonesia, II (a) \& (b)

${ }^{156}$ See for example L. Peskett and P. Yanda, (2009). The REDD+ Outlook: How Different Interests Shape the Future. London: Overseas Development Institute

${ }^{157}$ Ibid., p. 2

${ }^{158}$ Letter of Intent (LoI) Norway-Indonesia, VII (c)(i)

159 Telapak and EIA, (2011). Caught REDD Handed: How Indonesia's Logging Moratorium was Criminally Compromised on Day One and Norway will Profit. Bogor: Telapak and EIA

160 Project Design Note, (2007). Reducing Emissions from Deforestation in UluMasen Ecosystem, Aceh, Indonesia. Aceh: Provincial Government of Aceh, FFI and Carbon Conservation, p.2

${ }^{161}$ T. Mannand T. Surya, (2009). Op.Cit., p.65

162 Project Design Note, (2007). Op.Cit., p.13

${ }_{163}$ T. Mannand T. Surya, (2009). Op.Cit., p.67

${ }^{164}$ Project Design Note, (2007). Op.Cit., p.55 
according to a further Memorandum of Understanding [MoU] signed in July 2008, a Steering Committee will manage the distribution of the Project Account Funds. Members of the committee consist of the Governor of Aceh himself, one representative of Carbon Conservation, one from the FFI, one from Oxfam, and one representative of 61 villages who is appointed directly by the communities but nominated by the Governor. ${ }^{165}$ Hence, it is clear that the local communities are under-represented and although one representative is appointed directly by locals, it is likely that the Governor will nominate a person whom is closely tied to him. ${ }^{166}$

Moreover, the project is very risky to create conflicts with local communities or within the communities due to failure to recognise customary land rights over the project area ${ }^{167}$ and over simplification by allowing only one representative for 61 local communities in the Committee thus denying social dynamic of such community as a non-homogenous group.

As far as dispute resolution is concerned, the Singaporean International Arbitration Centre (SIAC) is referenced by the MoU as the only forum to seek justice with English as the official working language. Parties involved in dispute resolution have to be responsible for any cost during the proceeding. Although the MoU seems to provide access to justice to all stakeholders of the UluMasen project, the access available is financially and technically challenging for the local communities. ${ }^{168}$

Furthermore, although the Project Design Note says nothing about the strategy used to undertake forest protection procedure, news reportedly confirms that "the forest [area of the project] will be guarded by 1000 heavilyarmed former Free Aceh rebels" as stated by the Carbon Conservation Chief Executive (ABC 2008). ${ }^{169}$ Historically, after a long standing armed conflict in Aceh, the peace agreement between the GoI and the Free Aceh Movement have finally signed in 2005. In fact, using ex-combatants of the Free Aceh Movement for guarding the UluMasen project area may lead to re-militarisation which risks the peace agreement in Aceh. Indeed, as a private military, no regulation would be able to regulate the ex-combatants in their action committing wrongdoing or violating human rights. This legal loophole may bring traumatic experience and insecurity for Acehnese.

\section{B. Safeguards and Co-Benefits}

Although the main focus of the REDD+ mechanism is 'reducing emissions', the implications of the mechanism are connected to the issues of rights, land tenure, biodiversity etc. The international community is aware that REDD+ should be safeguarded and promote co-benefits. This is clearly stated in the Decision 2/CP.13, which stipulates that REDD (then REDD+) can "promote co-benefits and may complement the aims and objectives of other relevant international conventions and agreement" and "the need of local and indigenous communities should be addressed when action is taken to reduce emissions

\footnotetext{
${ }^{165}$ T. Mannand T. Surya, (2009). Op.Cit., p.68-69

166 Ibid.

${ }^{167}$ R.A. Clarke, "Moving the REDD Debate from Theory to Practice: Lessons Learned from the Ulu Masen Project". 6/1 Law, Environment and Development (LEAD) Journal, 2010. p.50

${ }^{168}$ T. Mannand T. Surya, (2009). Op.Cit., p.69-70

${ }^{169}$ ABC, (2008). Carbon Scheme Will Help Save Aceh Forest' on 11 April available at <http://www. abc.net.au/rural/news/content/200804/s2214030.htm> [accessed 14 August 2011]
} 
from deforestation and forest degradation in developing countries". ${ }^{170}$ Thus, it is worth discussing the extent to which the safeguards and co-benefits, especially the rights of indigenous people, biodiversity and ecosystem services, are implemented by REDD+ in Indonesia.

\section{The Rights of Indigenous Peoples}

In Indonesia, around 35-95 million people are considered indigenous people since they maintain their traditional way of life and distinct cultures. ${ }^{171}$ Despite the fact that they are recognised by the 1945 Indonesian Constitution ${ }^{172}$, there is no special, comprehensive, and more importantly, enforceable regime to protect their status and rights. A study conducted by Safitri and Bosko in 2002 is helpful to diagnose general types of laws and regulations on indigenous groups so called 'adatcommunities' in Indonesia. They conclude that laws and regulations on indigenous peoples in Indonesia are vague, partly regulated, normative in nature or not self-executing norms, and more importantly, intended to integrate indigenous peoples to the dominant society. ${ }^{173}$ In fact, the concept of integrating indigenous groups to the dominant society (assimilation) has been omitted by the International Labour Organisation (ILO)'s Conventions both No. 169 and No. 107, two most popular conventions in the context of indigenous peoples. Rather, they even go further to recognise the right to self-determination, which is further adopted by the United Nations Declaration on the Rights of Indigenous Peoples (UNDRIP) ${ }^{174}$.

Considering the lack of recognition of their status and rights, adat communities in Indonesia are very vulnerable to be marginalised in the implementation of REDD+. For decades they have faced injustices: being displaced and their ancestral areas being taken for commercial interests, such logging or palm oil plantation, and even for transmigration. ${ }^{175}$ Thus, it is plausible that adat communities are very sceptical to development agendas including the REDD+ projects since they have historical experience from many types of development schemes imposed by the government to their livelihood but they usually receive no benefit from the schemes.

Many indigenous groups and NGOs have pushed the inclusion of the principle of Free Prior and Informed Consent (FPIC) in designing the REDD+ architecture. In fact, little evidence has shown such principle has been implemented by the Government or developers of the REDD+ projects. ${ }^{176}$ Indeed, the principle that embraces that no development, administrative or other intervention should take place in an indigenous area "without the free, prior and informed consent of the indigenous peoples concerned"177 is essential

${ }^{170}$ Decision 2/CP.13, p.8, FCCC/CP/2007/6.Add.1, preambles

${ }^{171}$ Sawit Watch, and others, Request for Consideration of the Situation of Indigenous Peoples in Kalimantan, Indonesia, under the United Committee on the Elimination of Racial Discrimination's Urgent Action and Early Warning Procedures, Submitted on 6 July 2007 for the Seventy-First Session of the CERD, p.8

${ }_{172}$ Article 18B (2) of the 1945 Indonesian Constitution states "The State recognises and respects traditional communities along with their traditional customary rights as long as these remain in existence and are in accordance with the societal development and the principles of the Unitary State of the Republic of Indonesia and shall be regulated by law"

${ }^{173}$ NORAD, Op.Cit., p. 39-40

${ }^{174}$ Articles 3, 4 and 46 (1) of the UNDRIP, adopted in by the UN General Assembly Resolution $61 / 295$ on 13 September 2007 in New York

${ }^{175}$ See NORAD, Op.Cit., p.17

${ }^{176}$ NORAD, Op.Cit., p.43

177 See Articles 10, 19 and 32 (2) of UNDRIP 
for preventing the marginalisation of such peoples. Even for the Forest Carbon Partnership Facility (FCPF) Projects, the World Bank as the proponent of the initiative is more likely to use 'free prior informed consultation', as stated in its Operational Procedures, instead of implementing the principle of Free Prior Informed Consent (FPIC). ${ }^{178}$ Indeed, 'consultation' does not equal to 'consent' as being consulted prior the project implemented does not mean indigenous groups agree with it. ${ }^{179}$

Several attempts have been taken by indigenous groups and NGOs concerning the negative impacts of REDD+ on indigenous peoples for example by using complain procedures available at international fora, as well as by sending protest letters directly to the project developers. In July 2009, nine Indonesian organisations with their international network submitted communication to the Committee on the Elimination of Racial Discrimination (CERD) following two previous communications submitted in February 2009 and July 2007. The communication is complaining the failure of the Government to comply with the CERD's recommendations to review its laws and regulations that discriminate indigenous peoples including REDD+ policies in Indonesia. ${ }^{180}$ In February 2011, Yayasan Petak Danum (2011), a grassroots organisation based in Central Kalimantan, sent a protest letter to the Australian Delegates whom were visiting the Australia-Indonesia Kalimantan Forest Carbon Partnership (KFCP) site. Several issues on the KFCP project was raised, which are, among others, lacking recognition and respect for customary rights and local values, and lacking the inclusion of community inputs during the project activities. ${ }^{181}$

Despite such attempts above, indigenous peoples' status and rights are persistently being excluded from REDD+ policies. The Ministry of Forestry Regulation No.P.30/Menhut-II/2009 on "Reducing Emissions from Deforestation and Forest Degradation (REDD) Procedure", for instance, defines indigenous forest' as "state forest located in the area of customary law". ${ }^{182}$ 'State forest' is, in fact, defined as "a forest on lands which bear no ownership rights". ${ }^{183}$ These definitions are brought directly from Law No.41/1999 on Forestry which has proven being unable to respect and protect the rights of indigenous peoples and even creating land conflicts between indigenous peoples with governments as well as corporations. Although Law 41/1999 on Forestry states that the "Government shall stipulate the status of forest and indigenous forest shall be stipulated if any and its existence acknowledge"184 until now there is no regulation ensuring indigenous forests.

\footnotetext{
${ }^{178}$ See Paragraph 1 of the World Bank's Operational Procedures (OP) 4.10 on Indigenous Peoples

${ }^{179}$ For further analysis on the FPIC Process under the Forest Carbon Partnership Facility see K. Dooly, T. Griffiths, F. Martone, \& S. Oziga(2011)

${ }^{180}$ See Sawit Watch, and others, Request for Further Consideration of the Situation of Indigenous Peoples in the Republic of Indonesia under the Early Warning and Urgent Action Procedures, Submitted on 29 July 2009 for the Seventy-Fifth Session of the CERD

${ }^{181}$ See Yayasan Petak Danum Kalimantan Tengah (2011) Letter to the Australian Delegation to Central Kalimantan on 24 February 2011 available at <http://www.redd-monitor.org/2011/02/27/communityconcerns-with-the-kalimantan-forests-and-climate-partnership-no-rights-no-kcfp/> [accessed 15 August 2011]

182 Article 1(5) of The Ministry of Forestry Regulation No.P.30/Menhut-II/2009 on REDD Procedure

183 Article 1(4) of The Ministry of Forestry Regulation No.P.30/Menhut-II/2009 on REDD Procedure

${ }^{184}$ Article 5(3) of Law No.41/1999 on Forestry
} 
Another policy that has the potentials to discriminate indigenous peoples is the Ministry of Forestry Decree No.SK 159/Menhut-II/2004 on 'Ecosystem Restoration in Production Forests (ERC). The Decree establishes "conservation related area through a 100 year licence for the rehabilitation management of old logging concessions". This scheme works by prohibiting cutting trees and restricting the use of forest for non-timber products only. However, around 20 million hectares of forests under such scheme are within indigenous territory and the scheme potentially marginalises indigenous peoples and local communities from utilising the area. ${ }^{185}$

It seems unlikely that indigenous peoples would benefit from REDD+ considering the fact that their status and rights have been excluded by regulations in the first place. They are not considered to have rights on their territory, because according to the Indonesian legal system their territory is located within a state forest and the state forest cannot be titled a land right. This condition has caused severe conflicts in forestry sectors. Indeed, according to WALHI, 36\% of such conflicts are related to land rights or land tenure. ${ }^{186}$ Thus, if there is no change in the treatment to indigenous peoples taken by the Ministry of Forestry, it is likely that similar pattern in the exclusion of indigenous peoples would continue to happen under REDD+ and even may worsen the existing conflicts. Hence, in terms of equity, as one of the tools to assess REDD+, it is still a long way to go for the Indonesia's REDD+ projects to prove that they are capable of bringing about equity and benefit to adat communities.

\section{Biodiversity and Ecosystem Services}

Alarming rates in the loss of biodiversity has created two competing arguments on the relationship between REDD+ and biodiversity. Some argue that REDD+ would bring positive impacts on conservation of biodiversity since it would prevent DD in Indonesia's natural forests as the home of biological diversity ${ }^{187}$ ('co-benefit' of REDD+). On the other hand, others argue that unclear technical matters for example definition of 'forest' or the scope of REDD+ which includes sustainable forest management (SFM) would provide legal loopholes in its implementation. As a result, instead of intensifying activities that can avoid deforestation and forest degradation, REDD+ would provide 'extra income' for plantation companies to continue their expansion of monoculture plantation within natural forests.

In fact, the term 'co-benefits' is also contentious. The term implies that "benefits and synergies may arise through REDD, but their generation is only considered as a sub-ordinate goal". ${ }^{188}$ As REDD+ is merely focusing on forest carbon, it prioritises areas of forests that store as much carbon as possible to generate more payment, and is potential to overlook other important values of forests and their ecosystem services. In some cases, a forest area may have an essential role for preserving biodiversity and providing ecosystem services but it may be less valuable from the carbon perspective as the area may store a little amount of carbon. In this case, therefore, under the REDD+ schemes the area like

${ }^{185}$ NORAD, Op.Cit., p.42

${ }^{186}$ T. Mannand T. Surya, (2009). Op.Cit., p.27

${ }^{187}$ See for example C. Harvey and others. "Opportunities for Achieving Biodiversity Conservation through REDD". 20 Conservation Letters, 2009. Pp. 1-9

${ }_{188}$ T. Pistorius, (2009). Pitfalls and Opportunities for Mutual Addressing Climate Change and Biodiversity Conservation. Freiburg: Institute of Forest and Environmental Policy, p.13 
savannahs or non-forested wetland may be threatened by the needs to convert such an area into forest carbon projects in order to store more carbon in the area. ${ }^{189}$ Indeed, REDD+ is potential to be 'a double-edged sword' for biodiversity depending on how the architecture of REDD+ is designed. ${ }^{190}$

Indonesia with approximately 94 million ha of forest is considered as a country with mega-biodiversity. It contains $10 \%$ of plants, $12 \%$ of mammal species, $16 \%$ of birds, and 16 of world's reptiles and amphibians. ${ }^{191}$ However, based on the IUCN red list of threatened species, there are 174 mammal species, 90 birds, 30 amphibians, 3 reptiles, 21 plant species being listed as critically endangered, endangered, or vulnerable. ${ }^{192}$ One important area in Indonesia that provides ecosystem services for local communities and maintains biodiversity as well as contains a large amount of biomass is peat area. Despite the fact that a Presidential Decree No.32/1990 prohibits the development of peat areas deeper than 3 metres, development to convert such areas into plantation is still continued. ${ }^{193}$

Even, a REDD+ demonstration project under the Australia-Indonesia KCPF to rehabilitate a peat swamps area in Central Kalimantan is criticised by a group of peat scientists and practitioners because the project uses excavators and other heavy equipments to restore the areas. It is argued that the activity runs counter with REDD+ effectiveness in reducing emissions, since a large amount of GHG may be emitted during the rehabilitation activities and such activities are also harmful to the ecosystem, biodiversity and ecosystem services they provide. ${ }^{194}$

Since the locations of REDD+ may be different in ecological characteristic and environmental impacts, there is a need to undertake a strategic environmental assessment and environmental impact assessment before implementing REDD+. In Indonesia, the strategic environmental and environmental assessment (SEA and EIA) is required by Law No.32/2009 on Environmental Protection and Management ${ }^{195}$. However, it is unclear how many REDD+ projects have undertaken a SEA and EIA prior their activities although there is no requirement to do so in REDD+ policies. Therefore, it seems that the absence of requirement to undertake a SEA and EIA prior REDD+ activities in the REDD+ policies shows an attempt taken by the Government to trespass the environmental regulations in order to design REDD+ architectures as soon as possible. In fact, SEA and IEA is needed to assess the potential risks of a REDD+ project so that a most suitable scenario should be designed minimise the risks.

\section{Conclusion}

Forest plays a two-fold roles in the context of climate change. On the one hand, it is a carbon storage which absorbs GHG in the air, and stores them in its trees. On the other hand, forest is also a major source of emissions due to deforestation and forest degradation (DD) which contributes more than emissions from transportation and industries combined. Therefore, it seems

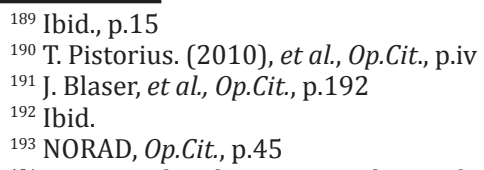

${ }^{194}$ For more detail see Press Release of UNPAR's Peat Scientist and Practitioners on 20 June (2011) available at <http://www.redd-monitor.org/2011/06/23/kalimantan-forests-and-climate-partnershipfaces-yet-more-criticism/> [accessed 16 August 2011]

${ }^{195}$ Article 22(1) of Law No.32/2009 
plausible that emissions from DD occurred mostly in developing countries have to be addressed by the international climate change regime in a post-2012 commitment.

A new scheme to reduce emissions in this context so called "Reducing Emissions from Deforestation and Forest Degradation plus Conservation, Sustainable Management of Forests, and Enhancement of Forest Carbon Stocks" $(\mathrm{REDD}+)$ has been discussed under the UNFCCC process, and it clearly will be "one of the key pillars of the post-2012 international climate regime". Despite many optimistic views on such scheme, much hard work needs to be done. Several issues remain unclear especially with regard to methodology, finance, leakage, and safeguards particularly indigenous peoples' rights and biodiversity.

However, since REDD+ is easily to be a 'side-edged sword' designing the regime in rush would create new problems or even worsen the existing problems. This tendency can be seen from a rush development of REDD+ architecture in Indonesia where DD is a very complex phenomenon involved socio-economic, environmental, as well as rights issues. If the causes of emissions from DD in Indonesia is not merely about economic development but is also related to forest governance and culture of corruption, it appears that injecting a large amount of money would not be the best solution. In fact, this injection would provide opportunities to maintain the culture of corruption within the government officials and local elites. Moreover, recognizing the status and rights of indigenous peoples is also an essential part in addressing forestry problems. This is because such people have proven themselves to be able to conserve the forests and to use it in sustainable manner for centuries.

Therefore, while the basic idea of REDD+ seems very noble and simple but in its details it is very complex. In fact, REDD+ objectives themselves appear to be contested. Carbon effectiveness, for instance, is possible to undermine co-benefits of REDD+ on biodiversity. As the need to reduce and absorb as many GHGs as possible increases, a concern on development of an effective GMO tree in this regard is alarming for biodiversity. Moreover, cost efficiency is possible to undermine the equity outcomes especially in the benefit sharing and participation, which requires equal sharing of benefit and high-cost in negotiating and obtaining agreement from all REDD+ stakeholders. Thus, a thorough assessment on the impacts REDD+ is needed so that it could balance all different interests in shaping an effective, efficient, equitable and co-benefit REDD+ scheme.

\section{Bibliography \\ Books}

Angelsen, A., (2009). Introduction in Realising REDD+: National Strategy and Policy Options. Ed. by Angelsen, A. Denmark: CIFOR

Angelsen, A., and Wertz-Kanounnikoff, S. (2008). What Are the Key Design Issues for REDD and the Criteria for Assessing Options? in Moving Ahead with REDD: Issues, Options and Implications. Ed. By Arild Angelsen. Bogor, Indonesia: CIFOR

Anger N., and Sathaye, J. (2008). Reducing Deforestation and Trading Emissions: Economic Implications for the Post-Kyoto Carbon Market. n.p: Centre for European Economic Research 
Blaser, J., Sarre, Poore, D., and Johnson, S. (2011). ITTO Technical Series No. 38: Status of Tropical Forest Management 2011. Yokohama, Japan: International Tropical Timber Organization, Yokohama

Bozmoski, A., and Hepburn, C. (n.d). The Interminable Politics of Forest Carbon: an EU Outlook. Oxford: Smith School of Enterprise and the Environment

Brand, U., et al. (2009). Contours of Climate Justice: Ideas for Shaping New Climate and Energy Policy. Uppsala: Dag Hammarskjold Foundation

Cabello, J. and Gilberston T. eds. (n.d). No REDD. Sonora, Mexico: Carbon Trade Watch and Indigenous Environmental Network

Dooly, K., Griffiths, T., Martone, F. \& Oziga, S. (2011). Smoke and Mirrors: A Critical Assessment of the Forest Carbon Partnership Facility. Brussel: FERN and Forest Peoples Programme

Ebeling, J. (2008). Risk and Criticisms of Forestry-Based Climate Change Mitigation and Carbon Trading in Climate Change and Forests: Emerging Policy and Market Opportunities. Ed.by. C. Streck et al. London: Royal Institute of International Affairs

Erni, C. and Tugendhat, H. (2010). What is REDD?: A Guide for Indigenous Communities. Chiang Mai, Thailand: AIPP, FPP, IWGIA and Tebtebba

Friends of the Earth International. (2008). REDD Myth: a Critical Review of Proposed Mechanisms to Reduce Emissions from Deforestation and Degradation in Developing Countries. Amsterdam: FOEI, Amsterdam

Friends of the Earth International. (2008). REDD: Realities in Black and White. Amsterdam: FOEI

Government of Indonesia. (2010). Draft National REDD+ Strategy. Jakarta: GoI and UN-REDD

Greenpeace. (2011). Bad Influence: How McKensey-Inspired Plans Lead to Rainforest Destruction. Amsterdam: Greenpeace International

Greenpeace. (2010). REDD Alert: Protection Money. Amsterdam: Greenpeace International

Griffiths, T. (2008). Seeing 'REDD'?: Forest, Climate Change Mitigation and the Rights of Indigenous Peoples and Local Communities. UK: Forest People Programme

Holloway, V. and Giandomenico, E. (2009). Carbon Planet White Paper: The History of REDD Policy. Adelaide: Carbon Planet Limited

Holmes, D. (2002). Where Have All the Forest Gone. Washington: World Bank

Hunt, Colin. (2009). Carbon Sinks and Climate Change: Forest in the Fight Against Global Warming. Cheltenham: Edward Elgar

International Labour Organization. (2003). The ILO Convention on Indigenous and Tribal Peoples, 1989 (No.169): A Manual. Geneva: ILO

IPCC. (2007). Climate Change 2007: Synthesis Report. n.p: IPCC

La Vina, A. (2010). The Future of REDD-Plus: Pathways of Convergence for the UNFCCC Negotiations and the Partnership. FIELD Working Paper.n.p: FIELD

Mann, T. and Surya, T. (2009). REDD Wrong Path: Pathetic Ecobusiness. Jakarta: WALHI 
NORAD.2010. Real-Time Evaluation of Norway's International Climate Forest Initiative: Contribution to National REDD+ Processes 2007-2010. Oslo: Norad

O'Sullivan, R. (2008). Reducing Emissions from Deforestation in Developing Countries: An Introduction' in Climate Change and Forests: Emerging Policy and Market Opportunities. Ed.by. C. Streck et al. London: Royal Institute of International Affairs

Parker, C., et al. (2007). The Little REDD Book. Oxford: Global Canopy Foundation

Peace, World Bank and DFID. (2007). Indonesia and Climate Change: Current Status and Policies. Jakarta: Peace

Peskett, L. and Yanda, P. (2009). The REDD+ Outlook: How Different Interests Shape the Future. London: Overseas Development Institute

Pistorius, T. (2009). Pitfalls and Opportunities for Mutual Addressing Climate Change and Biodiversity Conservation. Freiburg: Institute of Forest and Environmental Policy

Pistorius, T., Schmitt, C.,Benick, D., and Entenmann, E. (2010). Greening REDD+: Challenges and Opportunities for Forest Biodiversity Conservation. Freiburg: University of Freiburg

Project Design Note. (2007). Reducing Emissions from Deforestation in UluMasen Ecosystem, Aceh, Indonesia. Aceh: Provincial Government of Aceh, FFI and Carbon Conservation

Seymour, F., and Angelsen, A. (2009). Summary and Conclusions: REDD Wine in Old Wineskins?' in Realising REDD+: National Strategy and Policy Options. Ed.by ArildAngelsen. Denmark: CIFOR, Denmark

Sills, E., Madeira, M., Sunderlin, W., Wertz-Knounnikoff, S. (2009). The Evolving Landscape of REDD+ Projects in Realising REDD+: National Strategy and Policy Options. Ed.by ArildAngelsen. Denmark: CIFOR, Denmark

Stern, N. (2006). Stern Review on the Economics of Climate Change. London: HM Treasury

Telapak and EIA. (2011). Caught REDD Handed: How Indonesia's Logging Moratorium was Criminally Compromised on Day One and Norway will Profit. Bogor: Telapak and EIA

Trines, E. (2008). History and Context of LULUCF in the Climate Regime' in Climate Change and Forests: Emerging Policy and Market Opportunities. Ed.by. C. Streck et al. London: Royal Institute of International Affairs

Verchot L. and Angelsen, A. (2009). Box 7.2. Monitoring and Establishing Reference Levels in Realising REDD+: National Strategy and Policy Options. Ed.by. ArildAngelsen. Denmark: CIFOR, Denmark

Wertz-Kanounnikoff, S. and Angelsen, A. (2009). Global and National REDD+ Architecture: Linking Institutions and Actions in Realising REDD+:National Strategy and Policy Options. Ed.by. ArildAngelsen. Denmark: CIFOR

\section{Journal Articles}

Abate, R. "REDD, White and Blue: Is Proposed the US Climate Legislation Adequate to Promote a Global Carbon Credits System for Avoided Deforestation in a 
Post-Kyoto Regime?”. 19 Tulane J. of Int'l \& Com.Law, 2009. pp. 95-112

Bodansky, D. "The United Nations Framework Convention on Climate Change: A Commentary”. 18 Yale Journal of International Law, 1993. pp. 451-558

Brunnee, J. and Nollkaemper, A. "Between the Forests and the Trees: an Emerging International Forest Law”. 23 Environmental Conservation, 1996. pp. 307314

Clarke, R. A. "Moving the REDD Debate from Theory to Practice: Lessons Learned from the UluMasen Project". 6/1 Law, Environment and Development (LEAD) Journal, 2010. pp. 38-60

Clements, T. "Reduced Expectations: the Political and Institutional Challenges of REDD+". 44 Flora \& Fauna International, 2010. p. 309

Corbera, E., \& Schroeder, H. "Governing and Implementing REDD+". 14 Environ. Sci. Policy, 2011. pp. 89-99

French, D. "1997 Kyoto Protocol to the 1992 UN Framework Convention on Climate Change". 10 Journal of Environmental Law. 1998. pp. 227-239

Fry, Ian. "Reducing Emissions from Deforestation and Forest Degradation: Opportunities and Pitfalls in Developing a New Legal Regime". 17 RECIEL, 2008. pp. 166-167

Fry, Ian. "Twist in the Jungle: Exploring the Evolution of Land Use, Land-Use Change and Forestry Decisions within the Kyoto Protocol". 11 RECIEL, 2002. pp. 159-168

Grainger.et al. “Biodiversity and REDD at Copenhagen”. 19 Current Biology. 2009. pp. 974-976

Harvey, C.A. et al. "Opportunities for Achieving Biodiversity Conservation through REDD”. 20 Conservation Letters, 2009. pp. 1-9

Hufty, M., and Haakenstad, A. "Reduced Emissions for Deforestation and Degradation: A Critical Review". 5 The Journal of Sustainable Development, 2011. 1-24

Lesniewska, F. "REDD: the Copenhagen Effect". 6/1 Law, Environmental and Development Journal, 2010. pp. 104-111

Paoli, G., et al. "Biodiversity Conservation in the REDD". 5 Carbon Balance and Management, 2010. pp. 1-9

Streck, C. "Forest, Carbon Markets, and Avoided Deforestation: Legal Implications". 3 CCLR, 2008. pp. 239-247

Takacs, D. "Carbon into Gold: Forest Carbon Offsets, Climate Change Adaptation and International Law". 15 Hastings W.Nw. J. Envt'l L. \&Pol'y, 2009. pp. 39-87

Wertz-Kanounnikof, S. "Reducing Emissions from Deforestation and Degradation in Developing Countries (REDD): Insights from the UNFCCC COP-13 in Bali". 12 Iddri - Idees pour le debate, 2007. pp. 1-5

\section{Internet Sources}

ABC. 2008. Carbon Scheme Will Help Save Aceh Forest' on 11 April available at <http://www.abc.net.au/rural/news/content/200804/s2214030.htm> [accessed 14 August 2011] 
Ecologist. 2011. on 25 March <http://www.theecologist.org/News/news_ analysis/823928/pa> [accessed 26 March 2011]

FIELD. 2011. Guide for REDD-plus Negotiators. Available at <www.field.org.uk> [accessed 27 June 2011]

Ministry of Environment and Forests of India. 2009. Climate Change Negotiations: India's Submission to the United Nations Framework Convention on Climate Change (online) available at <http://www.moef.nic.in/downloads/home/ UNFCCC-final.pdf> [accessed 20 August 2011

Nation Online Website <http://www.nationsonline.org/oneworld/indonesia. htm> [accessed 20 August 2011]

Khor, M. 2010. What to Expect in Cancun: Some Key Issues. Third World Network (TWN) Cancun News Update 1. 29 November 2010. Available at <www. twnside.org.sg>

Lang, C. 2011. Why REDD+ is Dangerous. Available at <http://www.redd-monitor. org/2011/02/05/why-redd-is-dangerous-in-its-current-form/>

Li Lin, L. 2010. We'll Never Accept $2^{\text {nd }}$ Kyoto Period, says Japan, Sparkling Doubts on KP's Survival. Third World Network (TWN) Cancun News Update 5. 30 November 2010. Available at <www.twnside.org.sg>

REDD Monitor Website at <http://www.redd-monitor.org/2011/06/23/ kalimantan-forests-and-climate-partnership-faces-yet-more-criticism/> [accessed 16 August 2011]

Seagrass Indonesia Website at <http://seagrass-indonesia.oseanografi.lipi. go.id/en/news/36-3000-pulau-indonesia-akan-tenggelam.html>

The Jakarta Post Website at 24 <http://www.thejakartapost.com/ news/2010/09/24/kuntoro-mangkusubroto-chairs-redd-task-force. html $>$ [accessed 14 August 2011]

UNFCCC Secretariat Official Website at <http://unfccc.int>

Yayasan Petak Danum Kalimantan Tengah. 2011. Letter to the Australian Delegation to Central Kalimantan on 24 February 2011 available at http://www.redd-monitor.org/2011/02/27/community-concerns-withthe-kalimantan-forests-and-climate-partnership-no-rights-no-kcfp/ [accessed 15 August 2011]

\section{Submissions}

Sawit Watch, and others, Request for Consideration of the Situation of Indigenous Peoples in Kalimantan, Indonesia, under the United Committee on the Elimination of Racial Discrimination's Urgent Action and Early Warning Procedures, Submitted on 6 July 2007 for the Seventy-First Session of the CERD

Sawit Watch, and others, Request for Further Consideration of the Situation of Indigenous Peoples in the Republic of Indonesia under the Early Warning and Urgent Action Procedures, Submitted on 29 July 2009 for the SeventyFifth Session of the CERD 